Article

\title{
Participation as Relational Space: A Critical Approach to Analysing Participation in Sustainability Research
}

\author{
Livia Fritz * and Claudia R. Binder (10) \\ Swiss Mobiliar Chair in Urban Ecology and Sustainable Living, Laboratory for Human-Environment Relations \\ in Urban Systems (HERUS), Institute of Environmental Engineering (IEE), School of Architecture, Civil and \\ Environmental Engineering (ENAC), École Polytechnique Fédérale de Lausanne (EPFL), GR C1 455 (Bâtiment \\ GR)—Station 2, CH-1015 Lausanne, Switzerland; claudia.binder@epfl.ch \\ * Correspondence: livia.fritz@epfl.ch; Tel.: +41-216-933-803
}

Received: 24 April 2018; Accepted: 8 August 2018; Published: 11 August 2018

\begin{abstract}
In the field of sustainability, scholars, and policy-makers herald the transformative power of participation in knowledge production. However, a discrepancy between these expectations and the limited understanding of the complex interactions constituting participation processes can be observed. With the aim of critically analysing these complex interactions, this paper develops a conceptual perspective on participation as a relational space which is formed in the interplay of structures and processes. This perspective is applied to the analysis of empirical literature in sustainability research, development research, and science and technology studies. The literature review guided by the proposed conceptualisation systematically draws together the rich experience with participation in knowledge production. Elements constituting participation spaces along the dimensions 'structures' and 'actors' are identified and discussed in relation to 'processes' of space-making: (i) (in)coherences with reference system, (ii) resources, (iii) timing, (iv) expectations, (v) mutual trust, and (vi) worldviews and values. Power relations are found to pervade the three dimensions. Enhanced conceptual-analytical clarity of the elements constituting participation spaces provides a differentiated basis for discussing the transformative power of participatory knowledge production. By stimulating reflexivity on the making of participation, this approach contributes to better understanding when spaces of participation have the capacity to become spaces of transformation.
\end{abstract}

Keywords: spaces of participation; critical studies of participation; power relations; co-production; transdisciplinary sustainability research; transformation; relational approaches

\section{Introduction}

The United Nations resolution "Transforming our world: the 2030 Agenda for Sustainable Development" is the latest example in a series of international policy documents that stress the key role of science for sustainable development [1]. Facing complex and highly interconnected sustainability problems such as those embodied in the 17 Sustainable Development Goals of the Agenda 2030, the call for new approaches to science and the production of knowledge has gained momentum. Similar calls for the linking of scientific with 'local' and 'indigenous' forms of knowledge are already present in the Agenda 21 of the Rio Declaration in 1992 [2]. Over the past decades, scholars and policy-makers have increasingly questioned the capacity of 'traditional' disciplinary research alone to provide the kind of evidence needed for governing transformation processes towards sustainability $[3,4]$. They consider the reconceptualisation of science-society-policy relations indispensable for responding to the 'grand challenges' of climate change, environmental degradation, and rising inequalities within and across societies [5]. 
One part of this re-conceptualisation concerns the opening-up of research processes by including societal actors beyond the traditional scientific sphere [6]. Approaches to participation in knowledge production suggest that the idea of science holding a monopoly over the production of valid, trustworthy knowledge that should 'speak truth to power' fails in contemporary societies. These are characterised by complex problems, where neither science can claim truth nor polity can monopolise power [7]. The associated developments in science policy, and research practices have induced some scholars to announce a 'participatory turn' [8-10], a 'participatory return' [11], and a 'deliberative turn' [12], respectively. In the field of sustainability, participatory approaches, such as transdisciplinary (TD) research and real-world laboratories are seen as key for creating new knowledge, and achieving transformative change and innovation [13-16]. First used some 40 years ago by a physicist and early complexity researcher [17], today's conceptualisations of TD can be grouped into philosophy of science approaches (e.g., [18]) and sociological, actor-orientated approaches. In this article, we are primarily interested in the latter. Concerning these approaches, most scholars agree on three criteria according to which TD (i) departs from 'lifeworld' problems, (ii) integrates different scientific disciplines, (iii) includes non-scientific actors in the production of societally-relevant knowledge [19-21]. In these research areas, methods and tools have been developed with the expectation that the participation of non-scientific actors in research will produce robust knowledge [22], facilitate societal learning [23], foster trust in research results and commitment to the derived policies [24].

So far, scholars provide several tools to distinguish different types of participation and most importantly to categorise them according to motivation [25] and/or intensity of involvement [26]. While their strengths lie in the description and comparison of different forms of participation, they are poorly equipped for analytical enquiries into why participation in knowledge production takes different shapes, leading to different, and not always the desired, outcomes [27]. Furthermore, adopted from political science, commonly used conceptualisations of participation are elusive with regard to the epistemic ends of participation in knowledge production. Accordingly, in studies on the societal contribution of research projects, participation of different societal actors, both in transformative and transformation research [28], has mainly been conceived of as a static input factor into a larger transformation process (e.g., [29]). Hence, a discrepancy between the positive connotations of participation and the limited understanding of the dynamics and complex interactions constituting these knowledge production processes can be observed. In view of the growing number of research funding programmes requiring participation [30], analytical approaches to critically scrutinise participation processes in their complexity seem ever more important [31].

Literature on participation is widely dispersed and more recent approaches to participation in TD sustainability research hardly rely on theoretical and practical reflections derived from participation studies in more established fields. Learning potential has been identified for example for an integration of participation research from development studies (participatory rural appraisal, participatory action research) and science and technology studies (STS) (participatory technology and risk assessment) with sustainability research [32]. Across these fields, critical perspectives on the entanglement of knowledge and power in participation processes and on their embedding in societal structures have emerged [33-36]. In reaction, the need for reconceptualising participation as constructed [37], co-produced [9], and relational [38] has been identified.

In this paper, we follow this critical scholarship on participation and move away from the focus on isolated participation events in sustainability research, towards seeing participation as a relational space entangled with wider science-society relations. We ask which factors constitute and shape forms of participation in knowledge production. Relying on social theories of space, we propose a conceptual perspective that puts the emphasis on the processes of constituting participation. The main aim of this paper is to (i) bring complementary, yet largely parallel bodies of literature on participation in conversation (sustainability research, development research, STS); (ii) draw the contours of a relational perspective on participation as space; and (iii) apply this perspective to systematically integrate the 
findings of a qualitative literature review on factors shaping participation in case studies across the three scholarly fields.

This paper presents first ideas on how a shift in conceptual perspectives on participation can address missing dimensions in the current understanding of participatory knowledge production. Fostering conceptual-analytical clarity on the factors shaping participation spaces, this paper provides a differentiated basis for discussing the transformative power of participatory approaches to knowledge production. In scrutinising and problematising the very practice of participation which underpins various approaches to researching and governing sustainability issues, our findings feed into an emerging critical and transformative sustainability science which is sensitive to power dynamics and reflexive towards its own practices [39].

The paper is organised as follows: after a critical analysis of commonly used models of participation, Section 2 draws the contours of a relational perspective on participation as space at the research-practice interface and lays the conceptual foundation for the subsequent literature analysis. Section 3, provides a description of the methods applied. Building on the proposed perspective, Section 4 systematically integrates three bodies of literature with regard to potential factors shaping spaces of participation. Section 5 critically discusses the proposed perspective and outlines its contribution to critical and transformative sustainability sciences, before presenting conclusions.

\subsection{Deconstructing Models of Participation}

The myriad of discourses on participation in research and governance processes suggests that participation has been introduced in reaction to different kinds of problems. Put simply, in TD sustainability research, discrepancies between what we know about (un)sustainability and how we act are identified. In development research a lack of ownership and empowerment is problematised and with regard to science and technology decreasing public trust in new technologies is observed. Across the three fields participation of heterogeneous actors in the respective processes is seen as the answer to these problems. Accordingly, participation is associated with multiple ends and given diverse social, political and methodological meanings [32]. Despite this plurality there are common grounds when we speak of participation. Models of participation based on the degree of involvement, motivation, and nature of involvement are widely spread.

Across the scholarly fields analysed, several authors take up a vision of participation which was first outlined in the "Ladder of Participation" [40]. Relying on her experience as a community worker in the 1960s, Arnstein [26] categorises eight uses of the term participation arranged in a ladder pattern in which each rung corresponds to the degree of citizen power: manipulation and therapy, informing, consultation, placation and partnerships, delegated power and citizen control. Arnstein's model has marked a particular vision of participatory progress which reflects a linear logic of 'the more participation, the better'. Linked to this growth model, such conceptualisations assume a 'correspondence theory' of an external public, imagined to be waiting in a natural state for mobilisation by participatory methods. Ladder-inspired models are one-dimensional in the way that they conceptualise participation as a function of the degree of power which is intentionally handed over by the power-holding actors [9]. They rely on a realist understanding of 'power over' [41], e.g., the 'powerful' transfer or not some of their power to the initially 'powerless'. Discursive forms of power, such as the various effects emanating from intentional as well as unintentional practices and discourses of participation are omitted [42]. Linked to the dichotomisation of powerful/powerless, the ladder has been criticised for failing to capture the agency of those involved [31,43]. Furthermore, the ladder symbolism implies participation categories as static, which is inapt for grasping the "fluidity and flux of participation in practice" [44] (p. 3).

In TD literature, among those authors who elucidate their understanding of participation, different approaches are observable. In reference to Arnstein, Stauffacher et al. [45] develop a functional-dynamic model to analyse participation of non-scientific actors in TD research along the axes of information, consultation, cooperation, collaboration, empowerment. Schneider and Buser [46] 
rely on intensities of involvement to assess the degrees of stakeholder interaction which are the most promising for different types of research projects. Conceptualisations of participation specifically for knowledge production have been developed by Defila et al. [47] and by Boeckmann [48]. With slight variations, they understand participation as a continuum in which the roles of non-scientific actors range from being the object of research to being a partner actively forming the process. Both assume an indirectly proportional link between the number of actors involved and the intensity of involvement. Adaptations of Arnstein's model can also be traced in development research. These include Pretty's typology [49], which conceptualises motivations as crucial in shaping interventions, and White's [50] typology of interests which strives to unfold conflicting ideas about how participation is being used in different process phases. Additionally, in the literature on participation in governance of science and appraisal of technology three- and four-stage classifications based on Arnstein have become widely used [51].

Another common feature of participation and its analysis lies in the importance of intentionality attached to it $[25,52]$. Analytical attention has been focused on the motivation and rationale underlying participation out of which several categorisations emerged. Fiorino distinguishes between three imperatives underwriting participatory practices: normative (participation as an end in and of itself), substantial (participation aimed at achieving better outcomes), instrumental (participation aimed at securing particular interests) [53], each of which gives rise to different forms of participation. As an alternative to models based on the degree of involvement and type of motivation, respectively, Rowe and Fewer [54] emphasise the nature of involvement. They distinguish three forms of public engagement according to the flow of information: public communication (one-way), public consultation (one-way in the opposite direction), and public participation (two-ways). More recently, relational approaches to participation have been emerging. In STS, a rethinking of public involvement with science and environmental issues as co-produced [9] and of TD processes as 'adventures in relevance' [38] is proposed. These scholars claim that participation should not be taken for granted and identify the need to explore how it is constructed and situated in a wider intellectual environment [10].

The presented models which originate mainly in the field of planning and decision-making provide a valuable starting point for thinking of types and degrees of participation in research. However, they fall short in explaining why in different contexts participation processes evolve differently and do not reflect epistemic ends of knowledge production for sustainability. In particular, ladder-inspired approaches to participation echo ideals of deliberative democracy [55] and are guided by Habermasian principles of ideal speech [56]. Such approaches entail an emphasis on consensus-orientated over conflict-sensitive perspectives [57] and are accompanied by mostly descriptive accounts of the 'what' of participation. The 'how' and 'why' of different forms of participation are under-researched [58]. Participation is explained as a product of intentions of those setting up the process [59] while the context within which the process is embedded as well as actor relationships are neglected [38]. Despite the richness of case studies, single accounts have not systematically been brought together and participation has remained under-theorised [60].

\section{Towards a Critical Approach: Reconceptualising Participation as 'Relational Space'}

In this section, we shift the perspective away from the imaginaries of ladders and intensities of involvement and reconceptualise participation as a relational space. Upon this basis, we derive elements that are constitutive of participation spaces.

\subsection{Conceptualisations of Space}

On a metaphorical level many associations that we have with participation allude to a spatial dimension. For instance the idea of 'creating spaces' or 'making space' for different opinions to be expressed, and notions such as 'opening-up' or 'extending' opportunities for different actors to engage in certain activities, in our case, knowledge production, are frequently used in descriptions of participation [44]. Reviewed literature in the three fields provides several spatial analogies and 
metaphors, not directly focused on participation, but on related aspects of science-society relations. With their concept of "mode 2" Nowotny et al. [61] propound that the epistemological boundaries between the fields of science and society dissolve at least partially. At their intersection a common space emerges which they call the "agora". With reference to the Greek "political arena and the market place", they depict the interface as "a public space in which 'science meets the public' and in which 'the public speaks back to science'" [61] (p. 247). Other scholars rely on the symbolisms of space as an analytical perspective on social processes. These include Felt et al.'s [62] "epistemic living spaces" and Cornwall's "spaces for transformation" [24]. With regard to participation Gaventa [63] speaks of "invited, claimed and closed spaces", referring to who is involved in setting the cornerstones of participatory processes. He emphasises power relations inherent to participation and stresses the need for asking, who sets the foundations of the space which structure the interactions of participants.

In order to render the metaphor of participation as space operational as our analytical approach, further specification of our understanding of space is required. For such an operationalisation we rely on the German sociologist Martina Löw, who provides a comprehensive "sociology of space" [64]. She builds on work on spatiality by social theorists such as Simmel [65], Foucault [66], Bourdieu [67], Lefebvre [68] and advances an action-theoretical concept of space.

Löw posits that physical and social spaces need to be conceived as two elements of an integrated concept of space which is produced and transformed through performance. At the core of her proposition lies the conceptualisation of space as being relational. She defines relational space as a "[ ... ] relational arrangement of social goods and people in places" [69] (p. 200). The notion of arrangement (in the German original (An)Ordnung) refers to two aspects simultaneously: the arrangement as order (Ordnung) and the process of arranging or ordering (Anordnung).

Hence, a relational arrangement consists of both an action and a structural dimension. Order describes the structural dimension. With reference to Giddens, Löw describes structures as rules and resources, which are recursively embedded in institutions [69] (p. 226). Rules refer to the sanctioning of action and the constitution of sense. They are closely tied to resources, which according to Giddens "[ ... ] are media through which power is exercised, as a routine element of the instantiation of conduct in social reproduction" [70] (p. 16). Resources can be further distinguished in allocative resources (material resources based on the control of nature) and authoritative resources (symbolic resources based on people) [69].

Relational spaces are also always the result of processes (ordering). Löw identifies two key elements of space-making which form the action dimension in the constitution of space: synthesis and spacing. Firstly, spaces are not naturally pre-existing, but need to be actively (re)produced through processes of synthesis. Via processes of imagination, perception and memory, social goods and people are amalgamated to spaces. Secondly, these processes of synthesis are linked to processes of placing. The placing of social goods and people as well as of one-self is called spacing. Spacing processes are negotiation processes [69]. Both spacing and synthesis are dependent on action situations which are composed of material and symbolic components. Only what is available in an action situation can be synthesised and placed [71] (pp. 224-5). While people play a more active role than social goods in moving and making decisions, social goods are not passive objects in the constitution of space. Löw relies on the notion of social goods in order to emphasise symbolic aspects of material goods. In road infrastructure, for instance, a street sign is a material good, which is arranged specifically for its symbolic effect. Social goods are mainly arranged in accordance with material properties, though understanding these arrangements requires deciphering their symbolic properties. Social goods have an "external effectuality", for example in odours and sounds, which people perceive in different ways and thus influence the constitution of space [69] (p. 132).

The constitution of space through action usually does not take place in isolation, but is linked through negotiation processes with other actors. The negotiation of power relations is inherent to such processes [64] (p. 228). Bringing together the key notions described above, Löw provides an additional lens on the constitution of space that centres attention on inequality and power. In order 
to place social goods in relation to each other, access to those goods is required in the first place). Access possibilities might, however, be asymmetrically distributed and hence also the possibilities of shaping space [69] (p. 178). According to Löw, the opportunities to constitute space are restricted or enhanced due to (i) limited or increased possibilities of utilising social goods ("dimension of wealth"); (ii) limited or broader knowledge or credentials ("dimension of knowledge"); (iii) limited or increased possibilities of utilising social status ("dimension of rank"); and (iv) (non)-membership ("dimension of association") [69] (pp. 177-183).

Drawing on Giddens' structuration theory and Bourdieu's concept of habitus, in the concept of relational space action elements and structural order are understood as being in duality-the "duality of space" [71]. Any scientific analysis of space according to Löw has to consider structures and the characteristics of people and social goods as much as the interrelations amongst them. Only if both are understood and studied concomitantly, it becomes possible to grasp and analyse space. Consequently, space is not static, but dynamically (re-)figured. It furthermore is not absolute, but relative to who looks at it and might be perceived differently depending on actors' positions [69] (Table 1).

Table 1. Key elements in the constitution of relational space according to Martina Löw [69].

\begin{tabular}{|c|c|c|c|c|c|}
\hline \multirow{2}{*}{$\begin{array}{c}\text { Structures (orders) } \\
\text { Institutions }\end{array}$} & \multicolumn{2}{|c|}{ Bodies } & \multicolumn{2}{|c|}{ Processes (ordering) } & \multirow{2}{*}{$\begin{array}{c}\text { Access } \\
\text { Possibilities } \\
\begin{array}{c}\text { Dimensions of } \\
\text { Inequality }\end{array} \\
\end{array}$} \\
\hline & Social Goods & People & Synthesis & Spacing & \\
\hline $\begin{array}{l}\text { Structures are } \\
\text { rules/norms and } \\
\text { resources } \\
\text { embedded in } \\
\text { institutions; } \\
\text { spatial structures } \\
\text { are a form of } \\
\text { societal structures; } \\
\text { structural } \\
\text { principles e.g., } \\
\text { class and gender } \\
\text { permeate all } \\
\text { structures/actions }\end{array}$ & $\begin{array}{c}\text { Social goods have } \\
\text { both symbolic and } \\
\text { material } \\
\text { dimensions, e.g., a } \\
\text { street sign; } \\
\text { some are primarily } \\
\text { material, e.g., a } \\
\text { beamer in an } \\
\text { arrangement } \\
\text { 'meeting room'; } \\
\text { others are } \\
\text { primarily symbolic } \\
\text { e.g., values, songs }\end{array}$ & $\begin{array}{l}\text { Living beings } \\
\text { who are } \\
\text { arranged with } \\
\text { social goods }\end{array}$ & $\begin{array}{l}\text { Processes of } \\
\text { perception, } \\
\text { imagination } \\
\text { and memory, } \\
\text { guided by } \\
\text { notions of } \\
\text { space and } \\
\text { habitus }\end{array}$ & $\begin{array}{l}\text { Processes of } \\
\text { placing people } \\
\text { and social } \\
\text { goods or of } \\
\text { being placed, } \\
\text { includes } \\
\text { institutionalised } \\
\text { and } \\
\text { countercultural } \\
\text { action }\end{array}$ & $\begin{array}{l}\text { Wealth dimension } \\
\text { possibilities of } \\
\text { utilising social } \\
\text { goods; financial } \\
\text { resources; } \\
\text { knowledge } \\
\text { dimension: } \\
\text { knowledge and } \\
\text { credentials; } \\
\text { rank dimension: } \\
\text { possibilities of } \\
\text { utilising social } \\
\text { status; } \\
\text { association } \\
\text { dimension: } \\
\text { (non-)membership }\end{array}$ \\
\hline
\end{tabular}

\subsection{Implications for Studying Spaces of Participation}

In this sub-section we draw from Löw's concept of relational space and deduct a relational approach to studying participation. We adopt Löw's conceptualisation of the duality of structures (order) and actions (ordering) as the cornerstone of space-making. In analogy, in a participation process the scientific and non-scientific actors involved actively create a space for their interaction. This space is co-constituted by the surrounding societal structures.

Figure 1 schematically represents a process of space-making involving two persons. The actors (P1 and P2) involved in a research project enter into an action situation and position themselves therein (spacing). The process of entering into the action situation is determined by the characteristics of the actors as well as by the rules and norms in which they are embedded and the resources that are at their disposal. In this process of spacing also social goods are positioned. Once in the action situation processes of synthesis start. Through processes of perception actors link symbolic and material goods as well as other people to yield a space. During these processes of synthesis, they create a space within which participation can take place-the participation space. It becomes clear that depending on the constellation of actors and structures, different spaces of participation emerge from spacing and synthesis (Figure 1). An additional aspect is that these two key processes of spacing and synthesis (orderings) are shaped by and actively shape the surrounding structures (orders). 


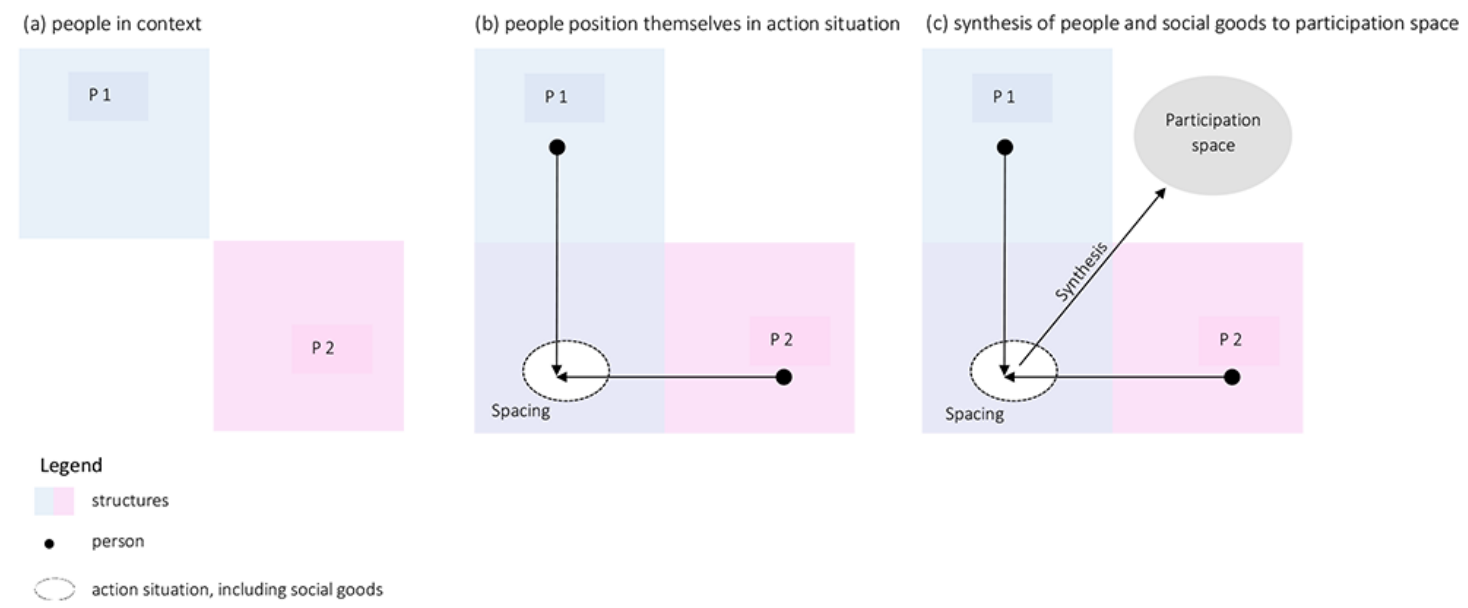

Figure 1. Conceptualising the constitution of a relational participation space (own illustration).

Based on this conceptual approach we derive the following analytical categories for studying participation as relational space (Table 2):

- Rules and norms are key elements in the constitution of participation spaces. For example, norms of how to do research influence the figuration of participation spaces. An analysis of participation, thus, needs to take into account its embeddedness in the respective societal structures (orders).

- Resources are closely tied to structures (orders) and recursively embedded in the institutions established in a field. An analysis of participation spaces requires an assessment of the kind of resources available.

- Actor characteristics and social goods shape arrangements and the figuration of spaces. Accordingly, an analysis of participation spaces needs to grasp which kinds of actors as well as material and symbolic goods are involved.

- Spacing and synthesis are the processes by which relational participation spaces emerge and become functional (ordering). Thus, analysing participation as space requires studying how actors and social goods position themselves/are placed (spacing) in an action situation. Concomitantly, processes of perception and imagination need to be studied through which people and social goods are combined to yield spaces of participation (synthesis).

- Across these four categories, mechanisms of inclusion and exclusion take place. Analysing the constitution of participation spaces requires to pay attention to access possibilities, determined, for example, by the distribution of resources amongst actors.

Table 2 displays the analytical questions that help us identify and systematically integrate the key elements shaping relational participation spaces from across the three scholarly fields. 
Table 2. Analytical questions for analysis of constitution of participation spaces adapted from Martina Löw's relational space (own representation).

\begin{tabular}{|c|c|c|}
\hline Dimension & $\begin{array}{l}\text { Key Elements Adapted for } \\
\text { Studying Participation as } \\
\text { Relational Space }\end{array}$ & Analytical Questions for Participation as Relation Space \\
\hline \multirow[t]{2}{*}{$\begin{array}{l}\text { I. Structures } \\
\text { (orders) }\end{array}$} & Rules and norms & $\begin{array}{l}\text { Which rules and norms do actors who are involved in the making of } \\
\text { spaces of participation relate to? } \\
\text { Which ways of functioning, of doing research or of interacting with } \\
\text { researchers have they routinized? } \\
\text { Which new rules have to be created for spaces of participation? } \\
\text { According to which rules are resources distributed amongst actors? }\end{array}$ \\
\hline & Resources & $\begin{array}{l}\text { Which resources are important to shape spaces of participation? } \\
\text { Which resources are available? } \\
\text { Which actors can rely on these resources? }\end{array}$ \\
\hline II. Actors & People and social goods & $\begin{array}{l}\text { What kind of people create spaces of participation? } \\
\text { Which kind of material and symbolic goods are available in an } \\
\text { action situation? }\end{array}$ \\
\hline $\begin{array}{l}\text { III. Processes } \\
\text { (ordering) }\end{array}$ & Synthesis and spacing & $\begin{array}{l}\text { How are people and social goods positioned in relation to each } \\
\text { other/how do they position themselves? } \\
\text { How close or how far away from each other are the actors (e.g., with } \\
\text { regard to their perceptions and expectations) and how does this } \\
\text { distance/closeness change throughout the process? } \\
\text { Which people and social goods are synthesised to spaces of } \\
\text { participation? } \\
\text { How are people and social goods linked to yield spaces of } \\
\text { participation? }\end{array}$ \\
\hline Transversal & Access possibilities & $\begin{array}{l}\text { Which mechanisms of inclusion and exclusion take place in the } \\
\text { constitution of spaces of participation? } \\
\text { Which role do wealth, knowledge, rank and association play? }\end{array}$ \\
\hline
\end{tabular}

\section{Materials and Methods}

This paper is based on a qualitative literature review of participation in knowledge production in sustainability research, development studies, and STS. In this section, criteria for selecting these three bodies of literature, the analytical procedure, and the types of material used are outlined.

\subsection{Selection of Bodies of Literature}

The focus lies on TD literature as a core discourse on participation in knowledge production in sustainability research. Literature from two other scholarly fields is included which are essential with regard to participation in knowledge production: (i) participation in development research and (ii) participation in STS. This choice is motivated by their relation to two of the key components of TD sustainability research as identified in the introduction:

(i) TD sustainability research is grounded in lifeworld problems and strives to provide solutions; what is considered a desirable solution is normatively guided by some idea of sustainability. Similarities to development research can be found, where participatory approaches strive at researching lifeworld problems and offering solutions guided by what is considered to be desirable development. A tradition of participation and inclusion of local knowledge in participatory rural appraisal (PRA) and participatory action research (PAR) has been formed over the past 50 years [72,73].

(ii) TD sustainability research consists of knowledge production processes and aims at integrating different forms of expertise. STS provides a wealth of experience in studying the mechanisms of science and practices of producing knowledge. Participation of heterogeneous actors in science and technology has become a key concern of STS [74]. Next to empirical analyses of "mode 2" research scholarly interest includes participation of "non-certified experts" [75] in technology and risk assessments. The latter emerged from the 1970ies onwards in reaction to public controversies surrounding techno-scientific programmes (e.g., nuclear power). Participatory assessments aim 
to involve "assessors other than scientists [ ... ] as fully-fledged social actors who bring not only their professional expertise (as farmers, campaigners, planners, business people, interest groups, etc.) to bear on the assessment but also their social expertise and experience" [76].

Despite their specificities, across the three fields participatory approaches deliberatively blur the boundaries and challenge the 'traditional' division of labour between research and practice.

\subsection{Selection and Description of Material}

In order to select publications on participation and similar practices under different headings in the three fields, a two-step procedure was followed. In a first exploratory step, a keyword search in 'google scholar' and 'web of science' using combinations of the following keywords was conducted: "participation, or transdisciplinary or co-production" and "sustainability research/science, or development studies/research or science and technology studies or technology assessment". Due to the high heterogeneity of meanings given to these notions, this step served exclusively as a basis for identifying an initial set of publications (e.g., meta reviews) and to become familiar with the use of terminology across the fields. In a second step, a snowball sampling approach was followed [77], whereby references provided in the initial set of publications led to the next set of publications. Due to the aim of bringing TD sustainability scholarship into conversation with parallel, but also earlier scholarship on participation, no specific time period was set for the inclusion of publications. Yet, only publications published up to 2017 were considered (Table 3). The earliest publication included in the sample is a PRA study from 1991 and the most recent ones are studies from the field of TD in sustainability research from 2017.

Table 3. Main criteria applied for inclusion/exclusion of publications.

\begin{tabular}{|c|c|}
\hline Criterion for Inclusion of Publication & Explanation \\
\hline Topical focus & $\begin{array}{l}\text { Sustainability-related (no sectoral focus set), development-related (focused on } \\
\text { developing countries and/or North-South context), science and } \\
\text { technology-related (focused on assessment of scientific, technological issues), } \\
\text { self-declared; }\end{array}$ \\
\hline \multirow[t]{2}{*}{$\begin{array}{l}\text { Minimum definition of participation in } \\
\text { knowledge production }\end{array}$} & $\begin{array}{l}\text { Participation: In order to operationalize the concept for the literature review, we } \\
\text { set the following minimum criteria (i) definitorial moment and (ii) structured } \\
\text { process. We understand participation as a spectrum including different forms } \\
\text { of interaction between actors from the research and the respective practice field } \\
\text { [47]. Participation starts where some degree of influence over the processes is } \\
\text { passed onto those participating. This presupposes a decision of the initial group } \\
\text { of actors to 'invite publics' [11]. In this understanding participation processes } \\
\text { are structured processes; }\end{array}$ \\
\hline & $\begin{array}{l}\text { Knowledge production: We focus on participation in processes aimed at } \\
\text { producing new knowledge. We rely on Mackinson et al. [78] to distinguish } \\
\text { these processes from policy processes primarily aimed at taking decisions; }\end{array}$ \\
\hline $\begin{array}{l}\text { Type of data I: case study-based or } \\
\text { empirical study }\end{array}$ & $\begin{array}{l}\text { Single and multiple case studies, empirical investigations about participation in } \\
\text { knowledge production and research; similar entities of research in terms of } \\
\text { scope and complexity: focus on concrete projects; theoretical reflections and } \\
\text { discussion of ideal-typical processes are excluded; case studies that exclusively } \\
\text { discuss the research output, but not the participatory process, are not } \\
\text { considered due to a lack of data; }\end{array}$ \\
\hline Type of data II: review & $\begin{array}{l}\text { Publications that deliver meta-analyses, research syntheses, and critical } \\
\text { evaluations of existing publications in the respective fields; }\end{array}$ \\
\hline Time-span: published up to 2017 & $\begin{array}{l}\text { The time-span of the qualitative review was deliberately wide so as to account } \\
\text { for different traditions in the respective fields. }\end{array}$ \\
\hline
\end{tabular}

Following the principle of saturation [79], 79 articles were reviewed (Table 4). The material includes monographs and edited volumes, journal publications, working papers and one project report. This variety allows us to take account of different publishing traditions in the three fields. Including sources beyond peer-reviewed journal publications has been considered of particular importance for studying TD processes [80]. Depending on the self-declared field to which the authors 
contribute, we attributed publications to one of the three fields. Where differences were not evident, we additionally considered the location of the case study (for development research), institutional affiliation of authors and journal. Since we are interested in participation processes (and not theoretical ideal-types) empirical and case study-based literature was selected. Due to the diversity between and within participatory approaches, similar reviews have identified the empirical and case study level as the most meaningful entity of analysis [81]. While case study is an elastic notion, it is here used to describe research in which one or several knowledge production projects are analysed in-depth or used in an exemplary way. Both self-reflections by researchers on their projects and empirical analyses of cases conducted by third parties are included. The cases cover various geographical regions and thematic foci in the area of developmental, environmental, and technological issues. In addition, the few available meta-analyses, as well as empirical enquiries that are not based on specific (own or third-party) projects, but address participation in empirical studies (e.g., interview and survey-based investigations), were considered. For the discussion and introduction, we included additional literature to contextualise our approach.

\subsection{Analytical Procedure}

Our approach is based on a qualitative in-depth analysis of each publication and applies a synthetic approach for qualitative studies [82]. Firstly, literature was examined and categorised by basic characteristics, i.e. publication category, main scholarly field, aim of the paper, type of actors involved, notion of participation used. Secondly, we extracted the empirical investigations relevant to understanding TD, participatory, knowledge production processes and the factors that shape them. While the suggested perspective on participation as relational space (Table 2) provided the frame for the analysis of the material, the sub-categories for elements presented in the results section were inductively derived from the analysis. A statement was considered a potential factor if explicitly mentioned by the authors as:

- a condition for success or failure of a participation process;

- a challenge to engagement;

- a (un)favourable precondition;

- having had an impact on the process; and

- guiding principles in order to achieve a 'good' process.

In an iterative process, we analysed, clustered, and discussed the empirical findings in relation to the conceptual perspective.

Table 4. Types and number of articles according to participation approach and scholarly field.

\begin{tabular}{cccc}
\hline $\begin{array}{c}\text { Field/Approach and } \\
\text { Type of Articles }\end{array}$ & Sustainability Research & Development Research & $\begin{array}{c}\text { Science and Technology } \\
\text { Studies }\end{array}$ \\
\hline Main approaches & $\begin{array}{c}\text { Transdisciplinary } \\
\text { research }\end{array}$ & $\begin{array}{c}\text { Participatory rural appraisal (PRA), } \\
\text { participatory action research (PAR); } \\
\text { transdisciplinary research }\end{array}$ & $\begin{array}{c}\text { Participatory risk assessment, } \\
\text { participatory technology } \\
\text { assessment; public engagement }\end{array}$ \\
Review articles & 7 & $/$ & 1 \\
Case study-based articles & 28 & 12 & 7 \\
(incl. self-reflections) & 9 & 3 & 1 \\
Other empirical articles & 1 & 7 & 3 \\
Additional & & & \\
\hline
\end{tabular}

\section{Results}

This section presents the results of the qualitative review of empirical and case study literature in three scholarly fields. Based on our conceptual perspective, we group the factors which are found to shape spaces of participation along the dimensions 'structures' and 'actors' and explore their role for 'processes' (Figure 1, Table 2). The dimension 'structures' refers to the systemic context within 
which action situations are embedded. Structural factors are grounded in the academic, but also in the respective practice field and are captured in structural and procedural aspects of research projects. The 'actors' dimension assembles factors which are tied to characteristics of individuals, as well as material and symbolic elements. The dimension 'processes' conceptually links the findings of the literature review to the key processes of space-making and explores the meaning of each element for spacing and synthesis. Table 5 summarises the findings and outlines their relation to the (re-)figuration of the participation space.

\subsection{Dimension I: Structures}

\subsection{1. (In)Coherence with Wider Reference System}

Numerous publications, particularly in the fields of sustainability research and STS, refer to the influence of the institutional setting and established structures within which TD and participatory research practices take place [83-85]. The fundamental importance of the wider context of science and technology governance lies both in its role in delimiting participatory processes and in being reciprocally shaped by their outcomes [51]. When it comes to the practicability of opening-up research, numerous challenges are identified. Many of these relate to the fundamentals of the academic system which are perceived as being constraining and in contradiction with participation spaces. The following tensions with the dominant structures are discussed: (i) participatory and integrative research vs. disciplinary career paths; (ii) the need to communicate findings to the involved non-scientific actors in a comprehensible form vs. the academic requirement of publishing in highly specialised, high-ranking scientific journals; and (iii) participatory processes are time-consuming vs. time constraints in externally-financed projects [6,85-91]. In a PRA study from 1990 similar tensions are discussed between the traditional criteria of project assessment and the potential merits of PRA [92]. This perceived inflexibility of the traditional structures is interpreted as an expression of the dominance of positivist epistemologies in scientific environments [93] and as a reflection of research traditions circumscribed by epistemological frameworks of highly specialised disciplines [92]. Schmid and Pröpper [89] trace these understandings of science in funding programmes and reward systems and argue that the influence of the science funding body over the TD process from its conception onwards determines the discourse on structural challenges. Felt et al. [59] (p. 4) find that also programmes explicitly designed for participatory or TD research "[ ... ] remain limited in scope as they operate in an environment in which this kind of cross-boundary work does not fit the established standards". These fields of tension suggest that researchers are exposed to conflicting reference systems $[84,94,95]$ which negatively affects their satisfaction as well as project effectiveness [95]. In reaction, some scholars call for the establishment of integrated institutions as a supplement to the disciplinary-based structures of research systems [96]. In an analysis of five projects embedded in a TD centre which was designed to act as a boundary organisation, commonly found challenges of insufficient participation and unbalanced problem ownership were not detected. However, this institutionalisation is found to entail new hybrid problems with regard to knowledge transfer and scalability [97].

Just as the scientific field, the idiosyncrasies of the respective practice field, in which participating non-scientific actors are embedded, might more or less encourage participating in knowledge production processes. In a study of PRA, Holmes [98] states that cultural traditions in the respective community influence participatory appraisals, but does not explicitly describe the nature of this impact. Furthermore, the kind of democratic culture in which a participatory endeavour is set might influence the motivation and ease of actors to participate [42,51,99]. With regard to TD processes Polk [100] (p. 12) stresses that "[p]olitical organizations have specific mandates, regulations and procedures" which differ from those of academic institutions. With the exception of such comments, the institutional norms that non-scientific actors adhere to have hardly been discussed in the TD literature reviewed.

Role for processes (spacing, synthesis): Regarding the constitution of participation spaces, these structural elements provide the frame for processes of synthesis and spacing (Figure 1). The norms to 
which scientific and non-scientific actors adhere affect which kind of participation is conceivable and how they position themselves in the action situation. Routines affect which elements actors synthesise by default to a participation space. In relation to these norms, scientific and non-scientific actors (re-)draw the boundaries between research and practice. Perceived incompatibilities of rule-sets lead to a clear delimitation of a participation space or might preclude the emergence of a participation space.

\subsubsection{Financial, Time, and Social Resources}

The availability of, and access to, resources is discussed with regard to success or failure of participation in knowledge production [37]. Time and financial resources are brought forward as decisive, but also competences are addressed as resources [101]. Scarcity of time for defining participatory activities, including time-consuming knowledge integration tasks, as well as rigid timelines, are seen as key issues constraining participation [45,93,102-105]. Felt et al. specify that "[...] what is regarded as an adequate duration and temporal structure of participatory events obviously impacts the possible ways in which matters of concern take form" [106] (p. 183). Likewise, the opportunity costs for participating non-scientific actors might be high and are often underestimated by the scientific counterparts $[104,107,108]$. Depending on the setting, opportunity costs vary, for example, in accordance with seasonality [98] or the priorities of those who are expected to participate might be with other issues [109]. Linked to time resources, the availability and distribution of financial resources is more or less conducive to certain forms of participation [110-114]. Financial restrictions during the development of research proposals shape the way the problem is defined and has repercussions on who is involved in this step [89]. The extent to which financial incentives are offered to participants shapes their capacity to engage and influences the participation process $[87,104]$. In the literature on participation in technology assessment, some authors take a critical stance on financial compensation. In a study on participation in the development of a local waste strategy, no evidence is found that financial compensation of those invited to participate would have increased their motivation or fundamentally altered the process [115].

In addition to financial and time resources, competences, and social capital of participants in the knowledge production process are considered resources shaping participation $[6,104,116]$. Tied to the institutional embedding of scientific actors, the specialised nature of scientific disciplines that most professionals are trained in rarely provides them with the skills needed for collaboration in heterogeneous teams [92].

Role for processes (spacing, synthesis): Financial, time, and social resources provide the conditions for actors to position themselves closer to, or with greater distance to, each other. The availability of resources affects the scope of the participation space (e.g., how many people can be mobilised; how often can meetings be arranged). The distribution of resources which is tied to rules and norms shapes the capacities of actors to actively engage in the making of participation spaces through synthesis.

\subsubsection{Timing of Participation}

The point in time when participation first occurs in a project is found to shape the evolution and outcomes of participation. The relevance of the timing of first involvement lies in the circumstance which actors take part in the initial definition of participation spaces. With regard to participation in technology assessments, partaking in front-end framing allows to influence the definition of problems and the design of alternative courses of action, rather than to only opt for predefined alternatives $[99,117]$. TD literature suggests that often initial project ideas originate in an academic context, with researchers then approaching whom they consider relevant non-scientific participants. These are typically taken on board after the funding proposals have been submitted and accepted $[59,83,88,118]$. Some authors ascribe this phenomenon to an incompatibility of co-design of project ideas and proposal-based research funding mechanisms $[89,91,119]$. The repercussions of late first involvement are controversially discussed. Numerous authors argue that whoever initially 
formulates the problem owns the process [120]. Not involving non-scientific actors in the initial phases of a project results in unbalanced problem ownership [45,87,91,101,118,120,121]. Early involvement is associated with increased legitimacy and relevance [90] and higher implementation chances for results [122]. In contrast, in an interview study with both scientific and non-scientific actors in TD projects, Di Giulio and Defila [123] find no evidence of such a path dependency with regard to the moment of first involvement. They show that involvement at a later stage is not necessarily perceived as problematic and matches the preferences of non-scientific participants who welcomed a traditional division of labour between scientific and non-scientific actors in early project phases. These controversial results illustrate the need for better understanding the reference system of non-scientific actors and their conception of science-practice relations.

Role for processes (spacing, synthesis): Timing is decisive for the question of who is entitled to pre-arrange social goods and to set the cornerstones of the participation space within a project (e.g., design of procedural aspects). As in early stages of knowledge production, the elements of the problem definition are set, the moment in time when involvement occurs affects the context in which the participation space is inscribed. By pre-defining and ascribing roles to different actors, those not involved in initial steps are passively positioned. Depending on the expectations of an actor this might (not) be perceived as undesirable.

\subsection{Dimension II: Actors}

\subsubsection{Expectations and Motivations}

Expectations of participants, the compatibility of different expectations and the degree to which they are met by the research process shape the interactions of heterogeneous actors $[91,113,123]$. Several challenges are addressed with regard to the ways in which expectations shape participation spaces. Renner et al. [122] report that scientists perceived the expectations of non-scientific participants to exceed general research requirements and to be poorly aligned with the scientific requirements that they had to fulfil. Regarding the management of expectations, they find that the diversity of worldviews present in a project increases the danger of discrepancy between expectations of scientific and non-scientific actors and negatively impacts on collaboration. Others mention challenges of sustaining the interest of non-scientific participants over the course of a project [87] and of reconciling open-ended research processes with clear expectations on process outcomes by non-scientific actors involved (e.g., of political actors) [90]. On the example of a TD development project, Habermann et al. [124] illustrate that unrealistically high expectations of local actors led to disappointment and reduced motivation for collaboration. McKee at al. [104] show that expectations of non-scientific actors can last beyond the official project end. In their case studies, researchers were seen as a precondition for the continuation of the process and expected to assume the roles of coordinators of dialogue. The dual role of researchers and possible incompatibilities of expectations can be particularly challenging when " $[t]$ he researcher's primary interest is to understand stakeholders' perspectives on the topic, therefore by sharing their opinion this outcome would not be achieved" [104] (p. 95). Expectations are linked to ownership and the motivation to engage in the making of participation spaces. Lacking ownership of and interest in the TD process on the side of non-scientific actors is found to be due to frustration and dissatisfaction because they "could not see any changes, only talking" [89] (p. 374). A self-reflection study including the view of the "practice partner", who was officially co-leader of the project, finds that the timeliness of an issue addressed positively affects the motivation and commitment of "practice partners" [102]. Overall, emphasis lies on how to manage expectations and less on the nature of expectations and motivations. Several authors consider the management of expectations from the very beginning as key to 'successful' processes $[48,111]$. In addition to expectations with regard to the process and its outcomes, expectations towards the respective others and the perceptions of their expertise might shape interactions between the actors involved [107]. In conceptualisations of 
participation in technology and risk assessment, the underlying motivation of those setting up the process play a prominent role [52] and serve as a basis of categorisations [25].

Role for processes (spacing, synthesis): Expectations of actors regarding the nature and the outcomes of the process shape the ways in which they position themselves in an action situation. The higher the perceived potential of the process, the closer actors might try to move towards the others. Expectations also shape perceptions of what the space should look like and suggest which other actors or which elements of a topic are synthesised. Expectations can change over the course of the project. If they are not fulfilled, actors might change their positions and move towards the periphery of the space. The greater expectations diverge the higher the likelihood of ruptures in the participation space. Consequently, commitment of actors to engage in the participation space and to take ownership for follow-up steps might decrease.

\subsubsection{Mutual Trust}

Development of trust between actors is highlighted as a precondition and success factor for participation [57,60]. Renner et al. [122] report that the absence of mutual trust among local partners and scientists lead to interrupted or declining participation of non-scientific actors. Similarly, in an empirical study on the roles of community development workers in PRA, the nature of the relations and the degree of trust between the community development worker and community are found to be key in enabling and preventing exchange [98]. The development of trust on the side of non-scientific participants relates to whether the researchers are perceived as being competent and capable of solving the problem that non-scientific actors face [114,125]. Furthermore, Maclure et al. [92] illustrate that the extent to which non-scientific actors, in their case farmers, feel they can impact on the process, shapes confidence-building and commitment. Mutual trust is seen as a precondition, as a deep-seated challenge and as potential outcome of TD processes [93]. In their reflections on a TD visioning process, McKee et al. [104] (p. 94) argue that "[ ... ] previous working relationships could generate more confidence that the overall TD process would be worthwhile for stakeholders and viewed as an opportunity for further interaction with academia, since the relationship precedes and exceeds the project timeframe". In addition to long lasting contacts, engaging on "equal footing" is described as essential for building trust [89]. In a study on ten TD collaborations, three strategies for building trust are identified: building on existing relationships, the use of intermediaries and guarantors and building trust through the project [126]. Reflecting on a PAR project, Dewulf et al. [127] highlight the importance of shared experience and common practice in order to allow tacit knowledge to be exchanged. In their experience with the participation of indigenous farmers in a project on irrigation systems in Ecuador, direct interaction between "communities of practice" cannot be replaced by intermediaries. Furthermore, the "chemistry" between actors and the extent to which personal characteristics of scientific and non-scientific actors in the team match influence their interactions [101]. Bell et al. [58] demonstrate the importance of group dynamics in shaping outcomes of participation.

Role for processes (spacing, synthesis): Scientific and non-scientific actors who are socially close to each other or who know each other leave less space between each other than do social strangers. The boundaries of this space in-between becomes tangible when one person transgresses them. This can lead to a distancing of the others. Trust in the competences and reliability of the others affects the extent to which the contributions of other participants are considered in the process of synthesis. Throughout the processes, trust can grow or decrease depending on the experience gained. The stronger the ties between the actors, the higher the capacity of the participation space to refigure in case of a changing context.

\subsubsection{Worldviews and Values}

The role of values and worldviews in shaping interactions of scientific and non-scientific actors is addressed in particular in sustainability and development research. When it comes to framing and solving sustainability problems different societal groups and actors express diverse and sometimes 
incommensurable values $[14,128,129]$. What is perceived as sustainable in a specific situation might vary considerably among actors and is likely to involve trade-offs. This plurality of values and perspectives feeds into the constitution of participation spaces [90,130,131]. Rosendahl et al. [35] understand situations of incongruity between non-scientific actors and researchers as an expression of pre-existing perceptions of the issue at stake. They highlight that researchers also hold positions in the "social matrix" and implicitly or explicitly bring their values into the research. The positions of researchers on how to deal with diverging worldviews and if and how participatory processes should strive for consensus differ. Some state that TD needs to cope with reconciling and assimilating competing worldviews [93]. Others argue that denying incommensurability in order to fulfil the principle of equal stance leads to a neglect of diversity and entails the translation of discordant knowledge into the dominant one $[117,132]$. In an interview study on the effectiveness of participatory appraisal of science and technology, one participatory process expert puts the fine line between finding common grounds while embracing difference in a nutshell: "[ .. ] being collegial and co-operating to understand each other [ . . ] [is desirable]. But if you push that too strongly then you are actually pushing a hegemonic sort of model" [117] (p. 173). In a comparison of 15 TD projects, the relation between partner diversity (including "values, norms and/or goals of partners", "view on science-society nexus") and project performance is found to be ambiguous. While the authors' analysis suggests negative effects of higher partner diversity, interview partners stressed the positive effects of diversity on creativity and conflict prevention [95]. In another TD study conducted within a boundary organisation, the scientific and non-scientific actors found constructive ways of dealing with diverging worldviews and diverse backgrounds. The authors see this as a reflection of "[ ... ] norms regarding how to handle different and conflicting opinions within the temporary practice“ [133] (p. 394).

Role for processes (spacing, synthesis): The role of worldviews and values for space-making is two-fold. Firstly, worldviews and values frame the ways in which scientific and non-scientific participants make sense of their environment. They guide actors in deciding which elements of a topic and which kind of knowledge are important and which changes in their environment are desirable. These decisions are critical for the ways in which actors synthesise elements to a participation space. Worldviews and values also play a role in how actors position themselves, e.g., if two actors share the perception of the problem they might move closer to one another. Secondly, worldviews and values are symbolic goods that are synthesised to a participation space.

\subsection{Power Relations [Transversal]}

Across the three fields scholars identify the need to further investigate unbalanced power relations and ways of addressing them $[60,72,85,86,125,134-136]$ and find that power relations influence the nature and process of participation $[89,119,122]$. Questions of power concern both relations between scientific and non-scientific actors and within non-scientific actor groups which might include heterogeneous actors, such as farmers and policy-makers [14].

The most visible form of power manifests itself in the distribution of resources. In a north-south TD collaboration, unequal starting positions and access to resources among African partners are found to have weakened ownership and commitment [89]. Similarly, Raymond et al. [137] attribute scientific dominance in two projects aimed at integrating local and scientific knowledge for environmental management to the unequal distribution of external funding. Even if all research phases are conducted jointly with partners, some actors might be more powerful than others, for example when researchers hold the coordination function and are in charge of time schedules [35]. Additionally, macro-societal structures, such as gender relations, might imply power relations amongst participants. This is, for instance, observed in an empirical study on PRA projects when women are not at ease to speak and share their experience in workshop settings [98]. Linked to the reproduction of macro-societal power relations, group dynamics embody another manifestation of power in participatory processes [58]. In an observation of TD case-based mutual learning sessions, the authority of some actors is found to be tied to their expertise or profound knowledge of the given issue. In the intercultural and 
international setting of this study, differences in discussion cultures are found to favour dominance of some actors [105]. Dominance of one or several individuals is observed both within a single action situation (e.g., a workshop) and over the course of a 3-4 years TD processes [133].

Most prominently in development research, the widespread adoption of participatory approaches was accompanied by critical voices on the concept and practice of participation [55,138-140]. The critique falls into two groups and puts power centre stage: (i) an internal critique of techniques and methods aimed at ameliorating practices of participation; (ii) a fundamental critique which unfolds power effects of participatory discourses [141]. In internal critiques of PRA processes reflexivity with regard to societal power relations is called for which are found to have "[ ... ] implications in [sic] the nature of involvement" [120] (p. 112). Representatives of the radical critique provocatively ask if participation has become "the new tyranny" [139]. Similarly, in the two other fields some scholars call for the use of facilitation techniques in mediating power dynamics. For example reserved participants should be actively encouraged to express themselves in action-oriented sustainability research [136]. Others argue that theories of public deliberation in the appraisal of science and technology should be refined so as to explicitly highlight " $[. .$. ] power relations and exclusions through confrontation, antagonism, and the exploration of difference" [117] (p. 179). In a network-based approach to knowledge systems, Munoz-Erickson et al. [142] observe that the knowledge of those holding power over resources was dominant. Knowledge about the issue under investigation had passed through the filter of values of the powerful actors. Thus, examining power becomes key to understanding "[ ... ] why more science does not necessarily lead to change and innovation" [142] (p. 189). In their case study the drawing of boundaries between different epistemic cultures emerged as a strategy to manage power. This boundary-work, however, entailed the privileged treatment of some expertise [142]. Along these lines, McKee et al. [104] (p. 95) stress that when "[ .. ] knowledge of researchers is highly valued [ ... ] there is a tendency for non-academic participants to become passive receivers of information". In such a situation greater authority is ascribed to scientific knowledge. Process design should facilitate the articulation of epistemological distinctions from the outset as to avoid imbalanced power relations [120]. Discussing collaborative research, Shdaimah and Stahl [57] suggest analysing power and control not only as a problem to be solved, but as an element inherent by default to collaboration processes.

Role for processes (spacing, synthesis): Power relations pervade synthesis and spacing and are reproduced or disrupted through them. In the case of an asymmetrical distribution of resources, those with fewer resources have limited opportunities to actively shape the constitution of a participation space. Possibilities of access to a participation space are also organised by way of knowledge. Exclusionary mechanisms are at play when some forms of knowledge are perceived as more credible and others as less valid or trustworthy. The norms that govern a participation space can favour the ways of reasoning, expressing, and behaving of one person/group. Those who do not dispose of resources, or whose resources are less recognised, can still be part of the participation space, but have limited possibilities of shaping its constitution. By determining who can effectively negotiate the design and use of space, access possibilities affect the extent to which figurations of a participation space break loose of societal structures and dominant discourses. 
Table 5. Overview of results in relation to key elements in the constitution of relational participation spaces (authors' own compilation).

\begin{tabular}{|c|c|c|c|c|}
\hline Dimension & $\begin{array}{l}\text { Key Element of } \\
\text { Relational Space } \\
\text { (Table 2) }\end{array}$ & $\begin{array}{l}\text { Element in } \\
\text { Literature }\end{array}$ & $\begin{array}{l}\text { Role for (re-)figuration of Space via } \\
\text { Processes of Spacing and Synthesis (III) }\end{array}$ & References \\
\hline \multirow{3}{*}{ I. Structures } & Rules and norms & $\begin{array}{l}\text { (In)Coherence with } \\
\text { wider reference } \\
\text { system }\end{array}$ & $\begin{array}{l}\text { Affects via rules and norms which } \\
\text { figurations of a participation space are } \\
\text { conceivable and which elements actors } \\
\text { synthesise; the norms to which actors adhere } \\
\text { affect how they position themselves; } \\
\text { incompatibilities of rule-sets lead to a clear } \\
\text { delimitation of the participation space; }\end{array}$ & {$[6,42,51,59,83-100]$} \\
\hline & Resources & $\begin{array}{l}\text { Financial, time and } \\
\text { social resources }\end{array}$ & $\begin{array}{l}\text { Affects possibilities and capacities of actors } \\
\text { to actively shape the participation space; } \\
\text { affects the degree of engagement of actors } \\
\text { and results in different degrees of } \\
\text { (a)symmetry of space; affects whether actors } \\
\text { position themselves/are positioned at the } \\
\text { core or periphery of the participation space; }\end{array}$ & $\begin{array}{l}{[37,45,87,89,92,93} \\
101-115]\end{array}$ \\
\hline & Resources & $\begin{array}{l}\text { Timing of } \\
\text { participation }\end{array}$ & $\begin{array}{l}\text { Affects who is entitled to set the cornerstones } \\
\text { of the participation space; affects through } \\
\text { synthesis in which context the participation } \\
\text { space is inscribed; by ascribing roles to } \\
\text { different actors, those not involved in initial } \\
\text { steps are passively positioned; might affect } \\
\text { the extent to which actors identify with the } \\
\text { aims and formats of participation; }\end{array}$ & $\begin{array}{c}{[45,59,83,87-99,101} \\
117-123]\end{array}$ \\
\hline \multirow{3}{*}{ II. Actors } & People social goods & $\begin{array}{l}\text { Expectations and } \\
\text { motivations }\end{array}$ & $\begin{array}{l}\text { Affects synthesis via perceptions of what is } \\
\text { an adequate dimension of the participation } \\
\text { space to reach a specific aim; incongruence of } \\
\text { expectations can lead to controversies and } \\
\text { ruptures in the participation space; affects } \\
\text { commitment of actors to engage in the } \\
\text { participation space and possibly ownership } \\
\text { for follow-up steps; }\end{array}$ & $\begin{array}{c}{[25,48,52,87,89-91} \\
102,104,107,111 \\
113,122-124]\end{array}$ \\
\hline & $\begin{array}{l}\text { People and social } \\
\text { goods }\end{array}$ & Mutual trust & $\begin{array}{l}\text { Affects distance between actors and whether } \\
\text { the knowledge of others is synthesised; } \\
\text { affects via the nature of ties between actors } \\
\text { the capacity of the participation space to } \\
\text { refigure in case of changing contexts; affects } \\
\text { the likelihood of institutionalisation of the } \\
\text { participation space; }\end{array}$ & $\begin{array}{c}{[57,58,60,89,92,93} \\
98,101,104,114,122 \\
125-127]\end{array}$ \\
\hline & $\begin{array}{l}\text { People and social } \\
\text { goods }\end{array}$ & $\begin{array}{l}\text { Worldviews and } \\
\text { values }\end{array}$ & $\begin{array}{l}\text { Affects potential conflicts of appropriation of } \\
\text { the participation space; which worldviews } \\
\text { are effectively synthesised, relates to } \\
\text { capabilities of actors to articulate them; } \\
\text { depending on the implicit norms with regard } \\
\text { to participation, controversy might be } \\
\text { embraced or deemed problematic; affects } \\
\text { which discourses outcomes feed into; }\end{array}$ & $\begin{array}{c}{[14,35,90,93,95,117} \\
128-133]\end{array}$ \\
\hline Transversal & $\begin{array}{l}\text { Resources, rules } \\
\text { and norms, people } \\
\text { and social goods }\end{array}$ & Power relations & $\begin{array}{l}\text { Affects the continuous negotiation processes } \\
\text { inherent to the figuration of a participation } \\
\text { space; affects the degree to which these } \\
\text { figurations reproduce or disrupt societal } \\
\text { structures and/or dominant discourses; } \\
\text { affects via the distribution of resources and } \\
\text { the validation of knowledge, inequalities } \\
\text { among actors and their capacity to produce } \\
\text { figurations of the participation space that } \\
\text { other participants share; }\end{array}$ & $\begin{array}{c}{[14,35,55,57,60,72} \\
85,86,89,98,104,105 \\
117,119,120,122 \\
125,133-142]\end{array}$ \\
\hline
\end{tabular}

\section{Discussion}

In this section, we conceptually link the core dimensions constituting relational spaces of participation and critically discuss the contribution of the proposed perspective to the emerging field of critical and transformative sustainability sciences, as well as its practical applicability. 


\subsection{Participation as Relational Space: Linking Structures, Actors, Processes}

In this paper, we deconstructed the dominant imagination of participation as ladder and its analytical focus on intensities of involvement. We reconceptualised participation as a relational space and looked at how it is figured and refigured in an interplay of structures and processes.

The findings of the qualitative literature review (Table 5) allow us to substantiate the conceptual approach presented (Figure 1). They show that several structural elements shape the positioning of scientific and non-scientific actors in an action situation (spacing). In the case of scientific actors, norms of 'sound' research practice, routinized ways of generating knowledge, and academic reward systems pre-arrange which social goods and people are perceived as being part of the situation. In tendency, actors position themselves in a way that allows them to uphold the requirements of their reference systems. The perceived incompatibilities with the wider academic system identified in the literature review might lead to greater distances and weaker ties between participants. In case of incompatibilities between the reference systems of scientific and non-scientific actors, actors might not find common ground in negotiating their positions. Closely tied to the institutional context, in most cases reviewed the distribution of resources for engaging in participation spaces is unequal. Whether a participation space is primarily embedded in a research setting or rooted in a specific practice field marks an important difference. Related to how the actors interpret the rules and norms, the characteristics of actors, as well as the available social goods shape processes of spacing. Expectations with regard to the process and its outcomes, worldviews, and values of actors, as well as prior experience in collaborating are found to be critical in this regard. Two actors who share a problem perception, hold the same vision of change and/or value the knowledge of the respective other, might position themselves closer to each other. The higher the expectations, the closer actors might try to move towards one another. How close they step together is also determined by the level of mutual trust. While conceptually separate, the processes of spacing and synthesis mostly take place in parallel in the constitution of participation spaces. Actors combine social goods, e.g., worldviews values, as well as other actors to yield a participation space. Which worldviews, values and knowledge are synthesised to a participation space affects into which discourses outcomes eventually feed. In this negotiation process unequal possibilities of constituting a participation space, e.g., due to limited access to resources, play an important role. The decisions on who and what is synthesised to a participation space are tied to the structural and actor-related elements mentioned (Table 5). Depending on the constellation of elements, the spaces of participation that emerge from spacing and synthesis take different shapes. These shapes can change throughout a project, as trust increases/decreases, expectations are fulfilled/disappointed or worldviews aligned/conflicting.

An additional aspect of the conceptual approach to participation as relational space is that spacing and synthesis are shaped by and actively shape the surrounding structures. In the short-term, within the duration of one project, our review did not provide examples of how norms and rules change. Over the long-haul, as alternative ways of synthesising spaces of participation are shared and reproduced by a growing number of actors, rules, norms and resources might transform. Our findings show that when looking beyond one specific action situation to the wider landscape of participation in research some examples can be found. Signs of how synthesis and spacing in a longer time horizon relate back to the surrounding structures can be seen in those cases in our literature review in which boundary organisations have been set up.

\subsection{Contribution to Critical and Transformative Sustainability Sciences}

The diverse elements that we identified in the literature review as shaping participation show the need for greater differentiation when we speak of participation and its role for producing 'socially robust' knowledge and for facilitating desired change processes. In particular, in the field of sustainability science this implies a clarification of whether we speak of participation primarily with regard to achieving change (e.g., transformative approach) or of participation with primarily epistemic ends (e.g., descriptive-analytical approach) [28]. Critique as method of descriptive distinguishing and 
a movement of differentiation has been considered key to critical sustainability sciences [143] and can help us to foster dialogue between transformative and descriptive-analytical approaches [144]. The problematisation of discourses and buzzwords constitutes an integral feature of critical social sciences [40]. The proposed perspective on participation as a relational space contributes to such a critical approach along the core dimensions of space-making: (i) structures: the politics of participation and the role of power, (ii) actors: 'situatedness' and the notion of agency, (iii) processes: from static input to dynamic process, and (iv) reflexivity and practical applicability.

\subsubsection{Structures: the Politics of Participation and the Role of Power}

Critical sustainability sciences require critical participation studies. In drawing attention to the figuring and refiguring of spaces of participation, the perspective on participation as relational space opens up the opportunity to address critical questions about the politics of and power inherent to participation.

The embeddedness of participation spaces in wider institutional landscapes requires paying attention to the politics of participation [145] and the normative dimensions inherent to all phases of participatory and TD sustainability research [146]. By emphasising the duality of structures and processes the proposed perspective helps to critically scrutinise the very norms, rules and resources that shape participation spaces and asks to which forms of interaction these are conducive. At the same time, this duality incites us to examine how spaces of participation shape norms and rules, e.g., of what 'good' and/or societally relevant research consists of and of how to assess the quality of expertise [75]. If fundamentally new rules emerge countercultural spaces might be formed which deliberatively break with routinized practices. In the literature reviewed, the rule-sets within which participation spaces are embedded are described as discouraging the emergence of open and interactive spaces. In extreme cases, incompatibilities of rule-sets render impossible the emergence of a participation space. Furthermore, the norms that govern a participation space can favour the habitus of one person/group and might lead to asymmetrical interactions. In drawing attention to these elements, the proposed perspective joins the call for conceiving participation not merely as a managerial-organisational challenge, but as an intrinsically political act $[141,147]$.

Understanding whose reality and knowledge counts [34] in critical and transformative sustainability sciences, unequivocally means addressing power [39]. The proposed perspective moves power to centre stage. The constitution of participation spaces is linked through negotiation processes to other spaces and includes debates about purpose and means of societal transformation [148]. In sustainability research the definition of sustainability or the weighting of elements of sustainability as much as the decisions on whose worldviews are synthesised embody such negotiations. Our findings show that in TD sustainability research primarily the distribution of resources amongst participants is discussed as a manifestation of power. Discursive, as well as productive forms of power (e.g., "power with" [149]) are not empirically addressed in depth. Neglecting or negating power asymmetries between participants might weaken the transformative potential of participatory research [35,60]. Seen from the perspective of participation as relational space, synthesis processes which are dominated by those holding the resources or the most normalised knowledge might hamper or even preclude the development of mutually shared perceptions of a participation space. A participation space that is shaped by one perspective is limited in the social goods, worldviews and values that are synthesised. Concomitantly the knowledge of less powerful actors might not be synthesised and innovation might be inhibited [142]. Our findings show that institutionalised practices of applying for project funding lead to a de facto exclusion of non-scientific actors from setting the cornerstones of participation spaces. By ascribing roles to actors, those not involved at this stage are passively positioned. Whether or not this is perceived as problematic depends on the motivations and expectations of the respective actors. By determining who negotiates the design and use of the participation space, power affects its potential to disrupt societal structures and dominant discourses. In case of highly unequal power relations, the capacity of a participation space to transform the societal status quo in which it is embedded is low. 
The proposed perspective provides guidance for a comprehensive study of power, taking into account mechanisms of inclusion and exclusion in the constitution of participation spaces. With regard to knowledge production processes, the four access possibilities (Table 2) are particularly useful to reflect on which knowledge is credible and in how far credibility is linked to association and membership of a specific group (e.g., academia). Addressing these issues is important to understand which expertise can be articulated and synthesised in a participation space, and/or which avenues for action are opened up/closed down [52].

\subsubsection{Actors: 'Situatedness' and the Notion of Agency}

One of the strengths of conceptualising participation with the help of Löw's sociology of space, lies in the relationality of the approach. Assuming that spaces of participation are not absolute forces us to consider that they might be experienced, perceived and delimited differently, depending on how synthesis takes place. Our literature review suggests that with a few exceptions e.g., [47,93,102,133] perspectives of non-scientific actors on participation and their embedding in wider institutional landscapes have been marginalised in scholarship on TD sustainability research. Greater sensitivity towards diverse perceptions and ways of synthesising might allow to better plan for results that are relevant for moving towards a more sustainable state. Focusing on the process of spacing and synthesis contributes to rethink actor understandings that underpin common conceptualisations of participation. A relational approach means seeing non-scientific participants not as passively waiting in a natural state to be mobilised [9], but as active agents in the making of participation. It incites us to study not only the perspectives and motivations of the 'architects of participation' [59], but also the active positioning and ways of synthesising of non-scientific actors, their strategies to appropriate and shape participation spaces in order to influence their desired outcomes. Paying attention to the 'situatedness' of actors and actor relationships $[38,44,134]$, entails moving beyond the dichotomisation of powerful/powerless actors as suggested by the metaphor of ladders. By highlighting the positioning of actors in relation to one another the proposed perspective opens up questions of identity construction [150] and otherness [151]. Furthermore, by stressing the role and 'effectuality' of social goods analysing participation as relational space calls for a wider understanding of actors, encompassing non-human and material elements. By highlighting the importance of positions, the relational approach also contributes to studying the 'situatedness' of knowledge [152] and its context-dependency. Contributing to such an understanding, our approach to studying participation allows conceiving of knowledge as positioned in participation spaces and, at the same time, as flowing between actors and institutions in processes of synthesis [153].

\subsubsection{Processes: from Static Input to Dynamic Process}

Understanding sustainability as an evolving process [143] requires critical and transformative sustainability sciences to be attentive to dynamics inherent to participation. So far, the dynamic nature of participation has hardly been captured in conceptual approaches [31] and weakly reflected in studies on the transformative effects of TD sustainability research [29]. Conceiving participation as a dynamic and complex process itself rather than as static input is prerequisite for better understanding when it leads to transformation and when it perpetuates an unsustainable status quo [27]. Relational spaces of participation are figured in action and are inherently dynamic. When studying participation as a relational space we found in our literature review that some participation elements are particularly dynamic, whereas others tend to be more stable. For instance, priorities of actors might change over time and expectations unmet at some stage of the process reduce commitment and motivation of actors to the process and its outcomes. Additionally, trust amongst actors might grow and enhance their commitment to take follow-up decisions based on process results. In contrast, rules and norms in the reference system tend to be stable over the course of a project. Our approach of participation as relational space posits that depending on the constellation of elements synthesised in a situation, participation takes different forms. These render some outcomes more likely than others. 
A constellation of elements, however, evolves with changes in its elements. Hence, the proposed approach allows us to consider the procedural nature of participation in both, primarily knowledge production and primarily action-orientated processes. In the short-term, the actors involved might be able to directly steer the dynamic elements. The more static structural elements might not be transformed by refining the formats of involvement and require a reflexive approach towards the ways in which the actors interpret and act upon structures [9].

\subsubsection{Reflexivity and Practical Relevance}

Reflexivity is a key element of critical research traditions [35] and the starting point for transformative approaches [16]. It can act as a bridging concept and inform the development of critical and transformative sustainability sciences. The multidimensional analytical grid presented (Table 2) can stimulate and guide reflexivity at different stages of the process: prospectively, when planning participation and retrospectively, when analysing participation. For those engaged in participatory knowledge production, it offers new ways of configuring the spaces between research and practice. Ex ante, the analytical categories provide guidance on which structural, process, and actor-related elements might shape the participation process. The perspective helps to differentiate between dynamic elements which can be actively addressed in planning and designing processes and more stable elements which require primarily a critical-reflection on the preconditions that frame actors' positioning and synthesis. Retrospectively, the analytical categories can structure a self-reflection on how the different elements and their relations affected the figuration of the participation space and the outcomes it produced. By proposing a change in perspective, the presented conceptualisation can also support research funding bodies and those reviewing research proposals to gain a fresh look at participation. For research funding bodies, in particular the dimension 'structures' of the proposed grid can support reflection on targeted funding requirements. During the assessment of research proposals, the perspective can complement the assessment of expected intensities of involvement (metaphor of the ladder) with a systemic view on the planned participation (metaphor of space). The proposed grid provides those reviewing the potential of a TD research project with critical questions for assessing whether the key elements of the structural, actor, and process dimensions are adequately considered in the process design.

\section{Conclusions}

In this paper, we developed a conceptual perspective for the analysis of participation in sustainability research. Adapting from Martina Löw's sociology of space, we conceived of participation in knowledge production as a relational space which is produced in the interplay of structures and actions. For studying the process of constructing participation, we proposed an analytical grid along the elements: rules/norms and resources (structures), people and social goods (actors), and synthesis and spacing (processes). Guided by this conceptualisation, literature on participation in sustainability research, STS and development studies was analysed. Despite the plurality of approaches and the specificities of each, drawing together experience from these diverse fields holds great potential for mutual learning with regard to factors that impinge on practices of participation. In particular, when moving beyond ideal-typical and theoretical reflections, boundaries blur and ways of addressing challenges in one field might be useful for other fields. Integrating empirical findings from the three fields, we identified several groups of elements along the dimensions 'structures' and 'actors' as potentially shaping participation spaces in knowledge production: (i) (in)coherences with reference system, (ii) resources, (iii) timing of participation, (iv) expectations, motivations, (v) mutual trust, (vi) worldviews and values. In addition, power relations were identified as interacting with elements across these dimensions. Relational spaces of participation are constituted through processes. Each of the elements affects the ways in which scientific and non-scientific actors position themselves in an action situation (spacing) and integrate them to yield a participation space (synthesis). The figuration of a participation space can dynamically change throughout a project, for example when 
trust increases/decreases, expectations are fulfilled/disappointed or worldviews aligned/conflicting. Structural elements such as rules and norms in the academic system tend to be more stable in the short term and require reflexivity with regard to the ways in which they frame each actor's positioning and synthesis. In extreme cases, incompatibilities of rule-sets preclude the emergence of a participation space. Furthermore, in case of highly unequal power relations, the capacity of a participation space to disrupt or transform the societal status quo in which it is embedded is low. Studying the elements identified (and possible additional ones) concomitantly we can arrive at a meaningful interpretation of the constitution of participation spaces. The need for further refinement notwithstanding, the proposed perspective on participation as relational space has the potential of being a useful step towards better understanding in which situations spaces of participation have the capacity to become spaces of transformation and change.

Author Contributions: This research was designed, carried out and written principally by L.F. L.F. developed the conceptual perspective, conducted the literature review and performed the analysis. C.R.B. supported the interpretation of findings and the discussion of results. Conceptualization, L.F. Methodology, L.F.; Formal Analysis, L.F.; Investigation, L.F.; Data Curation, L.F.; Writing-Original Draft Preparation, L.F.; Writing-Review \& Editing, L.F. and C.R.B; Visualization, L.F. and C.R.B.; Supervision, C.R.B..; Project Administration, L.F. and C.R.B..; Funding Acquisition, C.R.B.

Acknowledgments: This research is part of the project "Civil Society and Research for Sustainable Development: Demanding and Fostering Transdisciplinarity" (ZiFoNE) and was funded by the Ministry for Science and Culture of Lower Saxony/Germany. The authors would like to thank Silvia Hostettler for valuable feedback on earlier versions of this article. We thank three anonymous reviewers for their constructive and valuable comments.

Conflicts of Interest: The authors declare no conflict of interest. The founding sponsors had no role in the design of the study; in the collection, analyses, or interpretation of data; in the writing of the manuscript, and in the decision to publish the results.

\section{References}

1. United Nations. A /RES/70/1-Transforming Our World: The 2030 Agenda for Sustainable Development. In Resolution Adopted by the General Assembly; United Nations: New York, NY, USA, 2015.

2. United Nations. United Nations Conference on Environment \& Development Rio de Janerio, Brazil, 3 to 14 June 1992. Agenda 21; United Nations: New York, NY, USA, 1992.

3. Kates, R.W. What kind of a science is sustainability science? Proc. Natl. Acad. Sci. USA 2011, 108, 19449-19450. [CrossRef] [PubMed]

4. Miller, T.R.; Wiek, A.; Sarewitz, D.; Robinson, J.; Olsson, L.; Kriebel, D.; Loorbach, D. The future of sustainability science: A solutions-oriented research agenda. Sustain. Sci. 2014, 9, 239-246. [CrossRef]

5. European Commission. Horizon 2020. Work Programme 2016-2017. 16. Science with and for Society. European Commission Decision C(2017)2468 of 24 April 2017. 2015. Available online: http:/ / ec.europa.eu/ research/participants/data/ref/h2020/wp/2016_2017/main/h2020-wp1617-swfs_en.pdf (accessed on 10 August 2018).

6. Cornell, S.; Berkhout, F.; Tuinstra, W.; Tàbara, J.D.; Jäger, J.; Chabay, I.; de Wit, B.; Langlais, R.; Mills, D.; Moll, P. Opening up knowledge systems for better responses to global environmental change. Environ. Sci. Policy 2013, 28, 60-70. [CrossRef]

7. Hoppe, R. Policy analysis, science and politics: From 'speaking truth to power' to 'making sense together.'. Sci. Public Policy 1999, 26, 201-210. [CrossRef]

8. Bäckstrand, K. Civic science for sustainability: Reframing the role of experts, policy-makers and citizens in environmental governance. Glob. Environ. Politics 2003, 3, 24-41. [CrossRef]

9. Chilvers, J.; Kearnes, M. Remaking Participation: Science, Environment and Emergent Publics; Routledge: London, UK; New York, NY, USA, 2015; ISBN 1-135-08470-X.

10. Jasanoff, S. Technologies of humility: Citizen participation in governing science. Minerva 2003, 41, 223-244. [CrossRef]

11. Wynne, B. Public participation in science and technology: Performing and obscuring a political-conceptual category mistake. East. Asian Sci. Technol. Soc. 2007, 1, 99-110. [CrossRef]

12. Dryzek, J.S. Deliberative Democracy and Beyond: Liberals, critics, Contestations; Oxford University Press: Oxford, UK, 2000; ISBN 978-0-19-925043-1. 
13. Glass, J.H.; Scott, A.J.; Price, M.F. The power of the process: Co-producing a sustainability assessment toolkit for upland estate management in Scotland. Land Use Policy 2013, 30, 254-265. [CrossRef]

14. Pohl, C.; Rist, S.; Zimmermann, A.; Fry, P.; Gurung, G.S.; Schneider, F.; Speranza, C.I.; Kiteme, B.; Boillat, S.; Serrano, E. Researchers' roles in knowledge co-production: Experience from sustainability research in Kenya, Switzerland, Bolivia and Nepal. Sci. Public Policy 2010, 37, 267-281. [CrossRef]

15. Schneidewind, U.; Singer-Brodowski, M. Transformative Wissenschaft: Klimawandel im Deutschen Wissenschafts-und Hochschulsystem; Metropolis Marburg: Weimar (Lahn), Germany, 2013; ISBN 3-7316-1003-5.

16. Schneidewind, U.; Singer-Brodowski, M. Vom experimentellen Lernen zum transformativen Experimentieren: Reallabore als Katalysator für eine lernende Gesellschaft auf dem Weg zu einer Nachhaltigen Entwicklung. Z. Wirtsch. Unternehmensethik 2015, 16, $29-51$.

17. Jahn, T. Transdisciplinarity in the practice of research. In Transdisziplinäre Forschung: Integrative Forschungsprozesse Verstehen und Bewerten; Campus Verlag: Frankfurt am Main, Germany, 2008; pp. 21-37.

18. Mittelstraß, J. Wohin geht die Wissenschaft? Über Disziplinarität, Transdisziplinarität und das Wissen in einer Leibniz-Welt. Konstanz. Bl. Für Hochschulfragen 1989, 26, 97-115.

19. Hadorn, G.H.; Hoffmann-Riem, H.; Biber-Klemm, S.; Grossenbacher-Mansuy, W.; Joye, D.; Pohl, C.; Wiesmann, U.; Zemp, E. Handbook of Transdisciplinary Research; Springer: Zurich, Switzerland, 2008; ISBN 1-4020-6698-8.

20. Scholz, R.W.; Lang, D.J.; Wiek, A.; Walter, A.I.; Stauffacher, M. Transdisciplinary case studies as a means of sustainability learning: Historical framework and theory. Int. J. Sustain. High. Educ. 2006, 7, 226-251. [CrossRef]

21. Hansson, S.; Polk, M. Assessing the impact of transdisciplinary research: The usefulness of relevance, credibility, and legitimacy for understanding the link between process and impact. Res. Eval. 2018, 27, 132-144. [CrossRef]

22. Nowotny, H. Democratising expertise and socially robust knowledge. Sci. Public Policy 2003, 30, 151-156. [CrossRef]

23. Garmendia, E.; Stagl, S. Public participation for sustainability and social learning: Concepts and lessons from three case studies in Europe. Ecol. Econ. 2010, 69, 1712-1722. [CrossRef]

24. Gross, M.; Hoffmann-Riem, H. Ecological restoration as a real-world experiment: Designing robust implementation strategies in an urban environment. Public Underst. Sci. 2005, 14, 269-284. [CrossRef]

25. Renn, O.; Schweizer, P.-J. Inclusive risk governance: Concepts and application to environmental policy making. Environ. Policy Gov. 2009, 19, 174-185. [CrossRef]

26. Arnstein, S.R. A ladder of citizen participation. J. Am. Inst. Plan. 1969, 35, 216-224. [CrossRef]

27. Kropp, C. Demokratische Planung der Klimaanpassung? Über die Fallstricke partizipativer Verfahren im expertokratischen Staat. In Partizipation und Klimawandel-Ansprüche, Konzepte und Umsetzung; Oekonom: München, Germany, 2013; pp. 55-74. ISBN 978-3-86581-454-8. (In German)

28. Wittmayer, J.; Hölscher, K. Transformation Research: Exploring Methods for an Emerging Research Field; Texte; Umweltbundesamt: Dessau-Roßlau, Germany, 2018.

29. Walter, A.I.; Helgenberger, S.; Wiek, A.; Scholz, R.W. Measuring societal effects of transdisciplinary research projects: Design and application of an evaluation method. Eval. Program. Plan. 2007, 30, 325-338. [CrossRef] [PubMed]

30. Van der Hel, S. New science for global sustainability? The institutionalisation of knowledge co-production in Future Earth. Environ. Sci. Policy 2016, 61, 165-175. [CrossRef]

31. Collins, K.; Ison, R. Dare We Jump off Arnstein's Ladder? Social Learning as a New Policy Paradigm. In Proceedings of the PATH (Participatory Approaches in Science \& Technology) Conference, Edinburgh, Scotland, 4-7 June 2006; 2006.

32. Fritz, L. (De-)Constructing participation in transdisciplinary sustainability research: A critical review of key concepts. In Schafft Wissen-Gemeinsames und Geteiltes Wissen in Wissenschaft und Technik, Proceedings of the 2. INSIST Conference, 7-8 October 2016; Engelschalt, J., Maibaum, A., Engels, F., Odenwald, J., Eds.; Social Science Open Access Repository: Munich, Germany, 2018; pp. 106-125.

33. Kothari, U. Power, knowledge and social control in participatory development. In Participation: The New Tyranny? Kothari, U., Cooke, B., Eds.; Zed Books: London, UK, 2001; pp. 139-152.

34. Chambers, R. Whose Reality Counts? Putting the FIRST LAST; Intermediate Technology Publications Ltd. (ITP): London, UK, 1997; ISBN 1-85339-386-X. 
35. Rosendahl, J.; Zanella, M.A.; Rist, S.; Weigelt, J. Scientists' situated knowledge: Strong objectivity in transdisciplinarity. Futures 2015, 65, 17-27. [CrossRef]

36. Chilvers, J.; Burgess, J. Power Relations: The Politics of Risk and Procedure in Nuclear Waste Governance. Environ. Plan. A 2008, 40, 1881-1900. [CrossRef]

37. Hegger, D.; Lamers, M.; Van Zeijl-Rozema, A.; Dieperink, C. Conceptualising joint knowledge production in regional climate change adaptation projects: Success conditions and levers for action. Environ. Sci. Policy 2012, 18, 52-65. [CrossRef]

38. Klenk, N.L.; Meehan, K. Transdisciplinary sustainability research beyond engagement models: Toward adventures in relevance. Environ. Sci. Policy 2017, 78, 27-35. [CrossRef]

39. Brand, U. "Transformation" as a New Critical Orthodoxy: The Strategic Use of the Term "Transformation" Does Not Prevent Multiple Crises. GAIA-Ecol. Perspect. Sci. Soc. 2016, 25, 23-27. [CrossRef]

40. Huxley, M. Historicizing planning, problematizing participation. Int. J. Urban Reg. Res. 2013, 37, $1527-1541$. [CrossRef]

41. Hayward, C.R. De-Facing Power; Cambridge University Press: New York, NY, USA, 2000; ISBN 0-521-78564-2.

42. Cook, B.R.; Kesby, M.; Fazey, I.; Spray, C. The persistence of 'normal' catchment management despite the participatory turn: Exploring the power effects of competing frames of reference. Soc. Stud. Sci. 2013, 43, 754-779. [CrossRef]

43. Tritter, J.Q.; McCallum, A. The snakes and ladders of user involvement: Moving beyond Arnstein. Health Policy 2006, 76, 156-168. [CrossRef] [PubMed]

44. Cornwall, A. Making spaces, changing places: Situating participation in development. IDS Working Paper; Institute of Development Studies (IDS): Brighton, UK, 2002; Volume 170.

45. Stauffacher, M.; Flüeler, T.; Krütli, P.; Scholz, R.W. Analytic and dynamic approach to collaboration: A transdisciplinary case study on sustainable landscape development in a Swiss prealpine region. Syst. Pract. Action Res. 2008, 21, 409-422. [CrossRef]

46. Schneider, F.; Buser, T. Promising degrees of stakeholder interaction in research for sustainable development. Sustain. Sci. 2018, 13, 129-142. [CrossRef]

47. Defila, R.; Di Giulio, A.; Scheuermann, M. Forschungsverbundmanagement: Handbuch für die Gestaltung inter-und Transdisziplinärer Projekte; Vdf Hochschulverlag AG: Zurich, Germany, 2006; ISBN 3-7281-3042-7. (In German)

48. Boeckmann, T.; Dorsch, P.; Hoffmann, F.; Ohlhorst, D.; Schumacher, U.; Wulff, J. Zwischen Theorie und Praxis. Anregungen zur Gestaltung von Wissenschafts-Praxis-Kooperationen in der Nachhaltigkeitsforschung; Discussion Paper; Zentrum Technik und Gesellschaft: Berlin; Germany, 2005; Volume 17. (In German)

49. Pretty, J.N. Participatory learning for sustainable agriculture. World Dev. 1995, 23, 1247-1263. [CrossRef]

50. White, S.C. Depoliticising development: The uses and abuses of participation. Dev. Pract. 1996, 6, 6-15. [CrossRef]

51. Burgess, J.; Chilvers, J. Upping the ante: A conceptual framework for designing and evaluating participatory technology assessments. Sci. Public Policy 2006, 33, 713-728. [CrossRef]

52. Stirling, A. "Opening up" and "closing down" power, participation, and pluralism in the social appraisal of technology. Sci. Technol. Hum. Values 2008, 33, 262-294. [CrossRef]

53. Fiorino, D.J. Environmental risk and democratic process: A critical review. Columbia J. Environ. Law 1989, 14, 501.

54. Rowe, G.; Frewer, L.J. A typology of public engagement mechanisms. Sci. Technol. Hum. Values 2005, 30, 251-290. [CrossRef]

55. Cornwall, A.; Coelho, V.S. Spaces for Change? The Politics of Citizen Participation in New Democratic Arenas; Zed Books: London, UK; New York, NY, USA, 2007; Volume 4, ISBN 1-84277-553-7.

56. Habermas, J. Theorie des Kommunikativen Handelns; Suhrkamp: Frankfurt, Germany, 1981. (In German)

57. Shdaimah, C.; Stahl, R. Power and conflict in collaborative research. In Real Social Science: Applied Phronesis; Flyvbjerg, B., Landman, T., Schram, S., Eds.; Cambridge University Press: Cambridge, UK, 2012; pp. 122-137. ISBN 978-0-521-46850-3.

58. Bell, S.; Morse, S.; Shah, R.A. Understanding stakeholder participation in research as part of sustainable development. J. Environ. Manag. 2012, 101, 13-22. [CrossRef] [PubMed]

59. Felt, U.; Igelsböck, J.; Schikowitz, A.; Völker, T. Challenging participation in sustainability research. J. Deliberat. Mech. Sci. 2012, 1, 4-34. [CrossRef] 
60. Elzinga, A. Participation. In Handbook of Transdisciplinary Research; Springer: Zurich, Switzerland, 2008; pp. 345-359, ISBN 1-4020-6698-8.

61. Nowotny, H.; Scott, P.; Gibbons, M. Re-Thinking Science: Knowledge and the Public in an Age of Uncertainty; SciELO Argentina; Polity: Cambridge, UK, 2001; ISBN 0-7456-2608-4.

62. Felt, U. Knowing and Living in Academic Research: Convergences and Heterogeneity in Research Cultures in the European Context; Institute of Sociology of the Academy of Sciences of the Czech Republic: Prague, Czech Republic, 2009; ISBN 80-7330-156-3.

63. Gaventa, J. Finding the spaces for change: A power analysis. IDS Bull. 2006, 37, 23-33. [CrossRef]

64. Löw, M. Raumsoziologie; Suhrkamp Verlag: Frankfurt am Main, Germany, 2013; ISBN 518291068.

65. Simmel, G. Schriften zur Soziologie: Eine Auswahl; Suhrkamp Verlag: Frankfurt am Main, Germany, 1983; Volume 434, ISBN 3-518-28034-1. (In German)

66. Foucault, M.; Miskowiec, J. Of other spaces. Diacritics 1986, 16, 22-27. [CrossRef]

67. Bourdieu, P. Vom Gebrauch der Wissenschaft. Für eine Klinische Soziologie des Wissenschaftlichen Feldes; UVK Verlag: Konstanz, Germany, 1998; ISBN 978-3-87940-620-3. (In German)

68. Lefebvre, H. The Production of Space; Blackwell: Oxford, UK, 1991; Volume 142, ISBN 978-0-631-18177-4.

69. Löw, M. The Sociology of Space: Materiality, Social Structures, and Action; Springer: Berlin, Heidelberg, Germany, 2016; ISBN 978-1-137-48771-1.

70. Giddens, A. The Constitution of Society: Outline of the Theory of Structuration; University of California Press: Berkeley, CA, USA, 1984; ISBN 0-520-05292-7.

71. Löw, M. The constitution of space: The structuration of spaces through the simultaneity of effect and perception. Eur. J. Soc. Theory 2008, 11, 25-49. [CrossRef]

72. Lacroix, L.; Rist, S.; Gerritsen, P.R.; Péclard, D. Social and political participation in sustainable development with a focus on governance. In NCCR North-South. Research for Sustainable Development: Foundations, Experiences, and Perspectives; Geographica Bernensia: Bern, Switzerland, 2011; pp. 147-164.

73. Whyte, W.F.E. Participatory Action Research; Sage Publications, Inc.: Newbury Park, CA, USA, 1991; ISBN 0-8039-3742-3.

74. Abels, G. Forms and functions of participatory technology assessment-Or: Why should we be more sceptical about public participation? In Proceedings of the Participatory Approaches in Science \& Technology (PATH)'Conference, Edinburgh, Scotland, 4-7 June 2006.

75. Collins, H.M.; Evans, R. The third wave of science studies studies of expertise and experience. Soc. Stud. Sci. 2002, 32, 235-296. [CrossRef]

76. Joss, S. Toward the public sphere-Reflections on the development of participatory technology assessment. Bull. Sci. Technol. Soc. 2002, 22, 220-231. [CrossRef]

77. Noy, C. Sampling knowledge: The hermeneutics of snowball sampling in qualitative research. Int. J. Soc. Res. Methodol. 2008, 11, 327-344. [CrossRef]

78. Mackinson, S.; Wilson, D.C.; Galiay, P.; Deas, B. Engaging stakeholders in fisheries and marine research. Mar. Policy 2011, 35, 18-24. [CrossRef]

79. Onwuegbuzie, A.J.; Leech, N.L.; Collins, K.M. Qualitative analysis techniques for the review of the literature. Qual. Rep. 2012, 17, 1-28.

80. Brandt, P.; Ernst, A.; Gralla, F.; Luederitz, C.; Lang, D.J.; Newig, J.; Reinert, F.; Abson, D.J.; von Wehrden, H. A review of transdisciplinary research in sustainability science. Ecol. Econ. 2013, 92, 1-15. [CrossRef]

81. Brinkmann, C.; Bergmann, M.; Rödder, S.; Schuck-Zöller, S. Zur Integration von Wissenschaft und Praxis als Forschungsmodus-ein Literaturüberblick; Climate Service Center: Hamburg, Germany, 2015. (In German)

82. Noblit, G.W.; Hare, R.D.; Hare, R.D. Meta-Ethnography: Synthesizing Qualitative Studies; Sage: Newbury Park, CA, USA, 1988; Volume 11.

83. Felt, U.; Igelsböck, J.; Schikowitz, A.; Völker, T. Growing into what? The (un-) disciplined socialisation of early stage researchers in transdisciplinary research. High. Educ. 2013, 65, 511-524. [CrossRef]

84. Kläy, A.; Zimmermann, A.B.; Schneider, F. Rethinking science for sustainable development: Reflexive interaction for a paradigm transformation. Futures 2014, 65, 72-85. [CrossRef]

85. Wiek, A.; Farioli, F.; Fukushi, K.; Yarime, M. Sustainability science: Bridging the gap between science and society. Sustain. Sci. 2012, 7, 1-4. [CrossRef] 
86. Cvitanovic, C.; Hobday, A.; van Kerkhoff, L.; Wilson, S.; Dobbs, K.; Marshall, N. Improving knowledge exchange among scientists and decision-makers to facilitate the adaptive governance of marine resources: A review of knowledge and research needs. Ocean Coast. Manag. 2015, 112, 25-35. [CrossRef]

87. Siew, T.F.; Aenis, T.; Spangenberg, J.H.; Nauditt, A.; Döll, P.; Frank, S.K.; Ribbe, L.; Rodriguez-Labajos, B.; Rumbaur, C.; Settele, J.; et al. Transdisciplinary research in support of land and water management in China and Southeast Asia: Evaluation of four research projects. Sustain. Sci. 2016, 11, 813-829. [CrossRef]

88. Wuelser, G.; Pohl, C. How researchers frame scientific contributions to sustainable development: A typology based on grounded theory. Sustain. Sci. 2016, 11, 789-800. [CrossRef]

89. Schmidt, L.; Pröpper, M. Transdisciplinarity as a real-world challenge: A case study on a North-South collaboration. Sustain. Sci. 2017, 12, 365-379. [CrossRef]

90. Robinson, J.; Tansey, J. Co-production, emergent properties and strong interactive social research: The Georgia Basin Futures Project. Sci. Public Policy 2006, 33, 151-160. [CrossRef]

91. Talwar, S.; Wiek, A.; Robinson, J. User engagement in sustainability research. Sci. Public Policy 2011, 38, 379-390. [CrossRef]

92. Maclure, R.; Bassey, M. Participatory action research in Togo: An inquiry into maize storage systems. In Participatory Research; Sage Publications: Newbury Park, CA, USA, 1990.

93. Thompson, M.A.; Owen, S.; Lindsay, J.M.; Leonard, G.S.; Cronin, S.J. Scientist and stakeholder perspectives of transdisciplinary research: Early attitudes, expectations, and tensions. Environ. Sci. Policy 2017, 74, 30-39. [CrossRef]

94. Mattor, K.; Betsill, M.; Huayhuaca, C.; Huber-Stearns, H.; Jedd, T.; Sternlieb, F.; Bixler, P.; Luizza, M.; Cheng, A.S. Transdisciplinary research on environmental governance: A view from the inside. Environ. Sci. Policy 2014, 42, 90-100. [CrossRef]

95. Boon, W.P.; Chappin, M.M.; Perenboom, J. Balancing divergence and convergence in transdisciplinary research teams. Environ. Sci. Policy 2014, 40, 57-68. [CrossRef]

96. Mauser, W.; Klepper, G.; Rice, M.; Schmalzbauer, B.S.; Hackmann, H.; Leemans, R.; Moore, H. Transdisciplinary global change research: The co-creation of knowledge for sustainability. Curr. Opin. Environ. Sustain. 2013, 5, 420-431. [CrossRef]

97. Polk, M. Transdisciplinary co-production: Designing and testing a transdisciplinary research framework for societal problem solving. Futures 2015, 65, 110-122. [CrossRef]

98. Holmes, T. A Participatory Approach in Practice: Understanding Fieldworkers' Use of Participatory Rural Apprasial in ActionAid The Gambia; IDS Working Paper; Institute of Development Studies, University of Sussex: Brighton, UK, 2001; Volume 123.

99. Bond, A.; Palerm, J.; Haigh, P. Public participation in EIA of nuclear power plant decommissioning projects: A case study analysis. Environ. Impact Assess. Rev. 2004, 24, 617-641. [CrossRef]

100. Polk, M. Achieving the promise of transdisciplinarity: A critical exploration of the relationship between transdisciplinary research and societal problem solving. Sustain. Sci. 2014, 9, 439-451. [CrossRef]

101. Röckmann, C.; van Leeuwen, J.; Goldsborough, D.; Kraan, M.; Piet, G. The interaction triangle as a tool for understanding stakeholder interactions in marine ecosystem based management. Mar. Policy 2015, 52, 155-162. [CrossRef]

102. Binder, C.R.; Absenger-Helmli, I.; Schilling, T. The reality of transdisciplinarity: A framework-based self-reflection from science and practice leaders. Sustain. Sci. 2015, 10, 545-562. [CrossRef]

103. Bister, M.; Felt, U.; Strassnig, M.; Wagner, U. Zeit und Partizipation im transdisziplinären Forschungsprozes. In Transdisziplinäre Praxis. Forschen im Sozial-und Gesundhetiswesen; Reitinger, Elisabeth: Heidelberg, Germany, 2008; pp. 35-45. ISBN 978-3-89670-903-5. (In German)

104. McKee, A.; Guimaraes, M.H.; Pinto-Correia, T. Social capital accumulation and the role of the researcher: An example of a transdisciplinary visioning process for the future of agriculture in Europe. Environ. Sci. Policy 2015, 50, 88-99. [CrossRef]

105. Vilsmaier, U.; Engbers, M.; Luthardt, P.; Maas-Deipenbrock, R.M.; Wunderlich, S.; Scholz, R.W. Case-based mutual learning sessions: Knowledge integration and transfer in transdisciplinary processes. Sustain. Sci. 2015, 10, 563-580. [CrossRef] 
106. Felt, U.; Igelsböck, J.; Schikowitz, A.; Völker, T. Transdisciplinary Sustainability Research in Practice: Between Imaginaries of Collective Experimentation and Entrenched Academic Value Orders. Sci. Technol. Hum. Values 2016, 41, 732-761. [CrossRef]

107. Neef, A.; Neubert, D. Stakeholder participation in agricultural research projects: A conceptual framework for reflection and decision-making. Agric. Hum. Values 2011, 28, 179-194. [CrossRef]

108. Michener, V.J. The participatory approach: Contradiction and co-option in Burkina Faso. World Dev. 1998, 26, 2105-2118. [CrossRef]

109. Kesby, M. Spatialising participatory approaches: The contribution of geography to a mature debate. Environ. Plan. A 2007, 39, 2813-2831. [CrossRef]

110. Angelstam, P.; Andersson, K.; Annerstedt, M.; Axelsson, R.; Elbakidze, M.; Garrido, P.; Grahn, P.; Jönsson, K.I.; Pedersen, S.; Schlyter, P.; et al. Solving problems in social-ecological systems: Definition, practice and barriers of transdisciplinary research. Ambio 2013, 42, 254-265. [CrossRef] [PubMed]

111. Hanschitz, R.-C.; Schmidt, E.; Schwarz, G. Transdisziplinarität in Forschung und Praxis: Chancen und Risiken Partizipativer Prozesse; Springer: Berlin, Heidelberg, Germany, 2009; Volume 5, ISBN 3-531-16029-X. (In German)

112. Paulo Freire Zentrum. Verstehen, Was wir tun Systematisierung von Erfahrungen als Partizipativer Lernprozess; Schmid, E., Luger, A., Eds.; Paulo Freire Zentrum: Wien, Austria, 2015; Volume 12, ISBN 978-3-902996-04-6. (In German)

113. Stokols, D. Toward a science of transdisciplinary action research. Am. J. Community Psychol. 2006, 38, 63-77. [CrossRef] [PubMed]

114. Bayissa, D.D. Scrutinizing Factors Impeding Research-Farmer Relationship in the Context of the Agriculture Innovation System. Am. J. Bus. Manag. 2015, 4, 180-189. [CrossRef]

115. Petts, J. The public-Expert interface in local waste management decisions: Expertise, credibility and process. Public Underst. Sci. 1997, 6, 359-381. [CrossRef]

116. Steelman, T.; Nichols, E.G.; James, A.; Bradford, L.; Ebersöhn, L.; Scherman, V.; Omidire, F.; Bunn, D.N.; Twine, W.; McHale, M.R. Practicing the science of sustainability: The challenges of transdisciplinarity in a developing world context. Sustain. Sci. 2015, 10, 581-599. [CrossRef]

117. Chilvers, J. Deliberating competence: Theoretical and practitioner perspectives on effective participatory appraisal practice. Sci. Technol. Hum. Values 2008, 33, 155-185. [CrossRef]

118. Lang, D.J.; Wiek, A.; Bergmann, M.; Stauffacher, M.; Martens, P.; Moll, P.; Swilling, M.; Thomas, C.J. Transdisciplinary research in sustainability science: Practice, principles, and challenges. Sustain. Sci. 2012, 7 , 25-43. [CrossRef]

119. Whitman, G.P.; Pain, R.; Milledge, D.G. Going with the flow? Using participatory action research in physical geography. Prog. Phys. Geogr. 2015, 39, 622-639. [CrossRef]

120. Webber, L.M.; Ison, R. Participatory rural appraisal design: Conceptual and process issues. Agric. Syst. 1995, 47, 107-131. [CrossRef]

121. Ober, S. Demokratie und Wissenschaft. Eine Beziehung voller Widersprüche. Forum Wiss. 2016, 4, 9-14. (In German)

122. Renner, R.; Schneider, F.; Hohenwallner, D.; Kopeinig, C.; Kruse, S.; Lienert, J.; Link, S.; Muhar, S. Meeting the challenges of transdisciplinary knowledge production for sustainable water governance. Mt. Res. Dev. 2013, 33, 234-247. [CrossRef]

123. Di Giulio, A.; Defila, R.; Brückmann, T. “Das ist halt das eine ... Praxis, das andere ist Theorie"-Prinzipien transdisziplinärer Zusammenarbeit im Forschungsalltag. In Transdisziplinär forschen-zwischen Ideal und gelebter Praxis: Hotspots, Geschichten, Wirkungen; Defila, R., Di Giulio, A., Eds.; Campus Verlag: Frankfurt am Main, Germany, 2016; ISBN 3-593-50556-8. (In German)

124. Habermann, B.; Misganaw, B.; Peloschek, F.; Dessalegn, Y. Inter-and Transdisciplinary Research Methods in Rural Transformation; Habermann, B., Ed.; Austrian Development Agency: Vienna, Austria, 2013.

125. Bieluch, K.H.; Bell, K.P.; Teisl, M.F.; Lindenfeld, L.A.; Leahy, J.; Silka, L. Transdisciplinary research partnerships in sustainability science: An examination of stakeholder participation preferences. Sustain. Sci. 2016, 12, 87-104. [CrossRef]

126. Harris, F.; Lyon, F. Transdisciplinary environmental research: Building trust across professional cultures. Environ. Sci. Policy 2013, 31, 109-119. [CrossRef] 
127. Dewulf, A.; Craps, M.; Bouwen, R.; Abril, F.; Zhingri, M. How indigenous farmers and university engineers create actionable knowledge for sustainable irrigation. Action Res. 2005, 3, 175-192. [CrossRef]

128. Polk, M.; Knutsson, P. Participation, value rationality and mutual learning in transdisciplinary knowledge production for sustainable development. Environ. Educ. Res. 2008, 14, 643-653. [CrossRef]

129. Popa, F.; Guillermin, M.; Dedeurwaerdere, T. A pragmatist approach to transdisciplinarity in sustainability research: From complex systems theory to reflexive science. Futures 2015, 65, 45-56. [CrossRef]

130. Schneider, F.; Rist, S. Envisioning sustainable water futures in a transdisciplinary learning process: Combining normative, explorative, and participatory scenario approaches. Sustain. Sci. 2014, 9, 463-481. [CrossRef]

131. Schneider, F. Exploring sustainability through stakeholders' perspectives and hybrid water in the Swiss Alps. Water Altern. 2015, 8, 280-296.

132. Pellizzoni, L. Uncertainty and participatory democracy. Environ. Values 2003, 12, 195-224. [CrossRef]

133. Westberg, L.; Polk, M. The role of learning in transdisciplinary research: Moving from a normative concept to an analytical tool through a practice-based approach. Sustain. Sci. 2016, 11, 385-397. [CrossRef]

134. Cornwall, A. Spaces for transformation? Reflections on issues of power and difference in participation in development. In Participation: From Tyranny to Transformation; Hickey, S., Mohan, G., Eds.; Zed Books: London, UK; New York, NY, USA, 2004; pp. 75-91, ISBN 1-84277-460-3.

135. Fazey, I.; Evely, A.C.; Reed, M.S.; Stringer, L.C.; Kruijsen, J.; White, P.C.; Newsham, A.; Jin, L.; Cortazzi, M.; Phillipson, J. Knowledge exchange: A review and research agenda for environmental management. Environ. Conserv. 2013, 40, 19-36. [CrossRef]

136. Wittmayer, J.M.; Schäpke, N. Action, research and participation: Roles of researchers in sustainability transitions. Sustain. Sci. 2014, 9, 483-496. [CrossRef]

137. Raymond, C.M.; Fazey, I.; Reed, M.S.; Stringer, L.C.; Robinson, G.M.; Evely, A.C. Integrating local and scientific knowledge for environmental management. J. Environ. Manag. 2010, 91, 1766-1777. [CrossRef] [PubMed]

138. Christens, B.; Speer, P.W. Review essay: Tyranny/transformation: Power and paradox in participatory development. Forum Qual. Soc. Res. 2006, 7.

139. Cooke, B.; Kothari, U. Participation: The New Tyranny? Zed Books: London, UK, 2001; ISBN 1-85649-794-1.

140. Hickey, S.; Mohan, G. Towards participation as transformation: Critical themes and challenges. In Participation: From Tyranny to Transformation; Hickey, S., Mohan, G., Eds.; Zed Books: London, UK; New York, NY, USA, 2004; pp. 3-24. ISBN 1-84277-460-3.

141. Williams, G. Evaluating participatory development: Tyranny, power and (re)politicisation. Third World $Q$. 2004, 25, 557-578. [CrossRef]

142. Munoz-Erickson, T.A. Co-production of knowledge-action systems in urban sustainable governance: The KASA approach. Environ. Sci. Policy 2014, 37, 182-191. [CrossRef]

143. Jahn, T. Science for sustainable development requires a critical orientation. ISOE Discussion Paper; Institut fur sozial-ökologische Forschung: Frankfurt am Main, Germany, 2016; Volume 39.

144. Wiek, A.; Ness, B.; Schweizer-Ries, P.; Brand, F.S.; Farioli, F. From complex systems analysis to transformational change: A comparative appraisal of sustainability science projects. Sustain. Sci. 2012, 7, 5-24. [CrossRef]

145. Chilvers, J.; Longhurst, N. Participation in transition(s): Reconceiving public engagements in energy transitions as co-produced, emergent and diverse. J. Environ. Policy Plan. 2016, 18, 585-607. [CrossRef]

146. Scholz, R.W. The normative dimension in transdisciplinarity, transition management, and transformation sciences: New roles of science and universities in sustainable transitioning. Sustainability 2017, 9, 991. [CrossRef]

147. Cornwall, A. Unpacking 'Participation': Models, meanings and practices. Community Dev. J. 2008, 43, 269-283. [CrossRef]

148. Mobjörk, M. Consulting versus participatory transdisciplinarity: A refined classification of transdisciplinary research. Futures 2010, 42, 866-873. [CrossRef]

149. Allen, A. Rethinking power. Hypatia 1998, 13, 21-40. [CrossRef]

150. Massey, D. Politics and space/time. New Left Rev. 1992, 196, 65-84.

151. Bhabha, H.K.; Rutherford, J. Third space. Multitudes 2006, 3, 95-107. [CrossRef] 
152. Haraway, D. Simians, Cyborgs, and Women: The Reinvention of Nature; Routledge: New York, NY, USA, 2013; ISBN 0-415-90387-4.

153. Hardy, M.; Jobbling, H. Beyond power/knowledge-Developing a framework for understanding knowledge 'flow' in international social work. Eur. J. Soc. Work 2015, 18, 525-542. [CrossRef] 